\title{
Triterpene Glycosides from the Far Eastern Sea Cucumber Psolus chitonoides: Chemical Structures and Cytotoxicities of Chitonoidosides $\mathrm{E}_{1}, \mathrm{~F}, \mathrm{G}$, and $\mathrm{H}$
}

\author{
Alexandra S. Silchenko, Anatoly I. Kalinovsky, Sergey A. Avilov, Pelageya V. Andrijaschenko, Roman S. Popov, \\ Ekaterina A. Chingizova, Vladimir I. Kalinin * and Pavel S. Dmitrenok *iD
}

Citation: Silchenko, A.S.; Kalinovsky, A.I.; Avilov, S.A.; Andrijaschenko, P.V.; Popov, R.S.; Chingizova, E.A.; Kalinin, V.I.; Dmitrenok, P.S. Triterpene Glycosides from the Far Eastern Sea Cucumber Psolus chitonoides: Chemical Structures and Cytotoxicities of Chitonoidosides $\mathrm{E}_{1}$, F, G, and H. Mar. Drugs 2021, 19, 696. https://doi.org/10.3390/ md19120696

Academic Editor: Hitoshi Sashiwa

Received: 16 November 2021

Accepted: 6 December 2021

Published: 7 December 2021

Publisher's Note: MDPI stays neutral with regard to jurisdictional claims in published maps and institutional affiliations.

Copyright: (C) 2021 by the authors Licensee MDPI, Basel, Switzerland. This article is an open access article distributed under the terms and conditions of the Creative Commons Attribution (CC BY) license (https:/ / creativecommons.org/licenses/by/ $4.0 /)$.
G.B. Elyakov Pacific Institute of Bioorganic Chemistry, Far Eastern Branch of the Russian Academy of Sciences, Pr. 100-letya Vladivostoka 159,690022 Vladivostok, Russia; silchenko_als@piboc.dvo.ru (A.S.S.); kaaniv@piboc.dvo.ru (A.I.K.); avilov_sa@piboc.dvo.ru (S.A.A.); andrijashchenko_pv@piboc.dvo.ru (P.V.A.); popov_rs@piboc.dvo.ru (R.S.P.); chingizova_ea@piboc.dvo.ru (E.A.C.)

* Correspondence: kalininv@piboc.dvo.ru (V.I.K.); paveldmt@piboc.dvo.ru (P.S.D.); Tel./Fax: +7-(423)2-31-40-50 (V.I.K.)

\begin{abstract}
Four new triterpene disulfated glycosides, chitonoidosides $E_{1}$ (1), F (2), G (3), and H (4), were isolated from the Far-Eastern sea cucumber Psolus chitonoides and collected near Bering Island (Commander Islands) at depths of 100-150 m. Among them there are two hexaosides ( 1 and 3 ), differing from each other by the terminal (sixth) sugar residue, one pentaoside (4) and one tetraoside (2), characterized by a glycoside architecture of oligosaccharide chains with shortened bottom semi-chains, which is uncommon for sea cucumbers. Some additional distinctive structural features inherent in 1-4 were also found: the aglycone of a recently discovered new type, with 18(20)-ether bond and lacking a lactone in chitonoidoside G (3), glycoside 3-O-methylxylose residue in chitonoidoside $E_{1}(\mathbf{1})$, which is rarely detected in sea cucumbers, and sulfated by uncommon position 4 terminal 3-O-methylglucose in chitonoidosides $\mathrm{F}(2)$ and $\mathrm{H}$ (4). The hemolytic activities of compounds 1-4 and chitonoidoside E against human erythrocytes and their cytotoxic action against the human cancer cell lines, adenocarcinoma HeLa, colorectal adenocarcinoma DLD-1, and monocytes THP-1, were studied. The glycoside with hexasaccharide chains (1, $\mathbf{3}$ and chitonoidoside E) were the most active against erythrocytes. A similar tendency was observed for the cytotoxicity against adenocarcinoma HeLa cells, but the demonstrated effects were moderate. The monocyte THP-1 cell line and erythrocytes were comparably sensitive to the action of the glycosides, but the activity of chitonoidosides $\mathrm{E}_{\text {and }} \mathrm{E}_{1}$ (1) significantly differed from that of $\mathbf{3}$ in relation to THP-1 cells. A tetraoside with a shortened bottom semi-chain, chitonoidoside F (2), displayed the weakest membranolytic effect in the series.
\end{abstract}

Keywords: Psolus chitonoides; triterpene glycosides; chitonoidosides; sea cucumber; cytotoxic activity

\section{Introduction}

Triterpene glycosides are characteristic secondary metabolites of the sea cucumbers. Extensive studies on glycosides provide significant information on the exploration of chemical diversity, properties and biological activity of a huge collection of natural products, which are a valuable and promising resource of new drugs and medicines [1-8]. The interest in these compounds is also driven by their taxonomic specificity [9-11] as well as the possibility of reconstructing the sequences of the biosynthetic transformations of aglycones and carbohydrate chains during biosynthesis [12,13] and of defining the peculiarities of «structure-activity relationships» based on knowledge about their structural diversity [14]. All this indicates the relevance of searching for new glycosides. The Far Eastern sea cucumber Psolus chitonoides is the fourth chemically studied representative of the genus Psolus. The animals of this species contain a complicated multicomponent mixture of 
triterpene glycosides. Therefore, their separation and purification are difficult and timeconsuming. Recently, we published a paper concerning the isolation, structural elucidation, and biologic activity of a series of the glycosides, named chitonoidosides A-E, isolated from $P$. chitonoides [15]. These compounds feature some interesting structural features, such as a new, non-holostane aglycone lacking a lactone and featuring an 18(20)-epoxy cycle, 3-O-methylxylose residue in the carbohydrate chains of three of them, the sulfation of 3-Omethylxylose by $\mathrm{C}-4$, and, finally, a rather rare architecture of tetrasaccharide carbohydrate chain branched by C-4 Xyl1. As a continuation of our research on the glycosides from this species, four new chitonoidosides, $\mathrm{E}_{1}(\mathbf{1}), \mathrm{F}(\mathbf{2}), \mathrm{G}(\mathbf{3})$, and $\mathrm{H}$ (4), are reported. The chemical structures of 1-4 were established through the analyses of the ${ }^{1} \mathrm{H},{ }^{13} \mathrm{C}$ NMR, 1D TOCSY, and $2 \mathrm{D}$ NMR $\left({ }^{1} \mathrm{H},{ }^{1} \mathrm{H}-\mathrm{COSY}, \mathrm{HMBC}, \mathrm{HSQC}\right.$, and ROESY) spectra as well as HR-ESI mass spectra. All the original spectra are presented in Figures S1-S33 in the Supplementary Data section. The hemolytic activity against human erythrocytes and cytotoxic activities against human adenocarcinoma HeLa, colorectal adenocarcinoma DLD-1, and monocyte THP-1 cells were examined.

\section{Results and Discussion}

\subsection{Structural Elucidation of the Glycosides}

The concentrated ethanolic extract of the sea cucumber Psolus chitonoides was submitted to hydrophobic chromatography on a Polychrom-1 column (powdered Teflon, Biolar, Latvia). The glycosides were eluted after washing with water as a mobile phase to eliminate salts and inorganic impurities with 50\% EtOH. The obtained glycoside fraction was separated by the chromatography on Si gel columns with the stepped gradient of eluents $\mathrm{CHCl} / \mathrm{EtOH} / \mathrm{H} 2 \mathrm{O}$ (100:75:10), (100:100:17), and (100:125:25) to give the fractions (I-IV). The individual compounds 1-4 (Figure 1) were isolated by HPLC of the fractions III and IV on a silica-based column, Supelcosil LC-Si $(4.6 \times 150 \mathrm{~mm})$ and reversed-phase semipreparative column Supelco Ascentis RP-Amide $(10 \times 250 \mathrm{~mm})$.

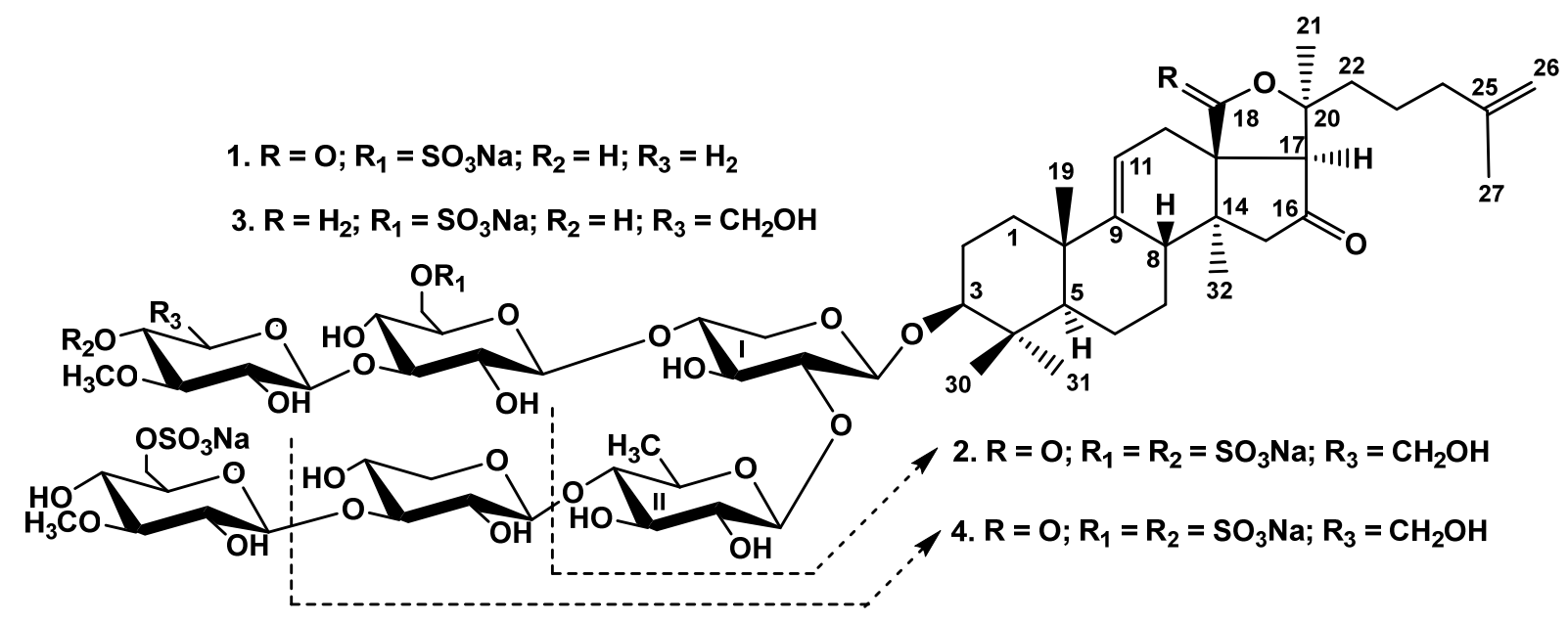

Figure 1. Chemical structures of glycosides isolated from Psolus chitonoides: 1—chitonoidoside $\mathrm{E}_{1}$; 2-chitonoidoside F; 3-chitonoidoside G; 4-chitonoidoside H.

The configurations of the monosaccharide residues in glycosides 1-4 were assigned as $D$ based on their biogenetic analogies with all other known sea cucumber triterpene glycosides.

It was found that chitonoidosides $\mathrm{E}_{1}$ (1), F (2) and $\mathrm{H}(4)$ are characterized by holotoxinogenin as aglycone, which was first found in Apostichopus japonicus and is broadly distributed in sea cucumber glycosides [16]. This was deduced from the analyses of their ${ }^{1} \mathrm{H}$ and ${ }^{13} \mathrm{C}$ NMR spectra (Tables S1-S3, Figures S1-S6, S9-S14 and S25-S31), which coincided with each other as well as with those of the aglycones of chitonoidosides $\mathrm{A}_{1}, \mathrm{C}$, and $\mathrm{D}$ isolated earlier from the same species-P. chitonoides [9]. 
The molecular formula of chitonoidoside $\mathrm{E}_{1}(\mathbf{1})$ was determined to be $\mathrm{C}_{65} \mathrm{H}_{100} \mathrm{O}_{36} \mathrm{~S}_{2} \mathrm{Na}_{2}$ from the $\left[\mathrm{M}_{2 \mathrm{Na}}-\mathrm{Na}\right]^{-}$ion peak at $m / z 1543.5315$ (calc. 1543.5339 ) and $\left[\mathrm{M}_{2 \mathrm{Na}}-2 \mathrm{Na}\right]^{2-}$ at $m / z 760.2734$ (calc. 760.2723) in the (-)HR-ESI-MS (Figure S8). The ${ }^{1} \mathrm{H}$ and ${ }^{13} \mathrm{C}$ NMR spectra of the carbohydrate chain of chitonoidoside $E_{1}(\mathbf{1})$ (Table 1, Figures S1-S7) were coincident with those for chitonoidoside E, isolated recently [15] and demonstrated six characteristic doublets of anomeric protons at $\delta_{\mathrm{H}} 4.67-5.11(\mathrm{~J}=7.1-8.0 \mathrm{~Hz})$ and six signals of anomeric carbons at $\delta_{C} 102.3-105.2$. The analysis of the ${ }^{1} \mathrm{H},{ }_{1}^{1} \mathrm{H}-\mathrm{COSY}, 1 \mathrm{D}$ TOCSY, HSQC and ROESY spectra of 1 resulted in the assignment of the signals of two xylose residues, one quinovose, one glucose and 3-O-methylglucose, as well as 3-O-methylxylose residues. The positions of the sulfate groups were determined based on the deshielding, due to $\alpha$-shifting effect, of the sulfate group's doubled signal at $\delta_{C} 67.1$, which is characteristic of glucopyranose units sulfated by C-6 (C-6 signals of non-sulfated glucopyranose residues are usually observed at $\sim \delta_{C} 61.2$ ). The signals of C-5 MeGlc4 and C-5 Glc5 were shielded due to the $\beta$-effect of the sulfate groups to $\delta_{C} 75.3$ and 75.5 , respectively. These data indicate the presence of a hexasaccharide chain with two sulfate groups attached to C-6 MeGlc4 and to C-6 Glc5, and 3-O-methylxylose residue as the sixth sugar unit in chitonoidoside $E_{1}(\mathbf{1})$. The sequence of monosaccharides and the positions of the glycosidic bonds were confirmed by the correlations $\mathrm{H}-1 \mathrm{Xyl} / \mathrm{H}-3$ (C-3) of the aglycone, H-1 Qui2/H-2 (C-2) Xyl1, H-1 Xyl3/H-4 (C-4) Qui2, H-1 MeGlc4/H-3 (C-3) Xyl3, H-1 Glc5/H-4 (C-4) Xyl1, and H-1 MeXyl6/H-3 (C-3) Glc5 in the ROESY and HMBC spectra of 1, respectively (Table 1, Figures S5-S7).

Table 1. ${ }^{13} \mathrm{C}$ and ${ }^{1} \mathrm{H}$ NMR chemical shifts, HMBC and ROESY correlations of carbohydrate moiety of chitonoidoside $\mathrm{E}_{1}(\mathbf{1})$.

\begin{tabular}{|c|c|c|c|c|}
\hline Atom & $\delta_{C}$ Mult. $^{a-c}$ & $\delta_{\mathrm{H}}$ Mult. $(J \text { in } \mathrm{Hz})^{d}$ & НMBC & ROESY \\
\hline \multicolumn{5}{|c|}{ Xyl1 $(1 \rightarrow C-3)$} \\
\hline 1 & $104.8 \mathrm{CH}$ & $4.67 \mathrm{~d}(7.1)$ & $C: 3$ & H-3; H-3, 5 Xyl1 \\
\hline 2 & $82.2 \mathrm{CH}$ & $3.96 \mathrm{~m}$ & C: 1 Qui2 & H-1 Qui2 \\
\hline 3 & $75.1 \mathrm{CH}$ & $4.16 \mathrm{~m}$ & & $\mathrm{H}-1,5$ Xyl1 \\
\hline 4 & $77.9 \mathrm{CH}$ & $4.16 \mathrm{~m}$ & & H-1 Glc5 \\
\hline \multirow[t]{2}{*}{5} & $63.5 \mathrm{CH}_{2}$ & $4.38 \mathrm{dd}(4.3 ; 12.2)$ & C: 3 Xyl1 & \\
\hline & & $3.64 \mathrm{~m}$ & & H-1 Xyl1 \\
\hline \multicolumn{5}{|c|}{ Qui2 $\left(1 \rightarrow 2 X_{y l} 1\right)$} \\
\hline 1 & $104.6 \mathrm{CH}$ & $5.03 \mathrm{~d}(8.0)$ & C: 2 Xyl1 & H-2 Xyl1; H-3, 5 Qui2 \\
\hline 2 & $75.7 \mathrm{CH}$ & $3.87 \mathrm{t}(8.0)$ & C: 1, 3 Qui2 & \\
\hline 3 & $74.8 \mathrm{CH}$ & $3.98 \mathrm{t}(9.3)$ & C: 2 Qui2 & H-1 Qui2 \\
\hline 4 & 85.6 CH & 3.49 t (9.3) & C: 1 Xyl3; 3, 5 Qui2 & H-1 Xyl3 \\
\hline 5 & $71.4 \mathrm{CH}$ & $3.67 \mathrm{dd}(6.2 ; 9.3)$ & & H-1 Qui2 \\
\hline 6 & $17.8 \mathrm{CH}_{3}$ & $1.61 \mathrm{~d}(6.2)$ & C: 4, 5 Qui2 & H-4 Qui2 \\
\hline \multicolumn{5}{|c|}{ Xyl3 (1 $\rightarrow$ 4Qui2) } \\
\hline 1 & $104.5 \mathrm{CH}$ & $4.75 \mathrm{~d}(7.7)$ & C: 4 Qui2 & H-4 Qui2; H-3, 5 Xyl3 \\
\hline 2 & $73.2 \mathrm{CH}$ & $3.84 \mathrm{t}(8.5)$ & C: 1 Xyl3 & \\
\hline 3 & 87.1 CH & $4.04 \mathrm{t}(8.5)$ & C: 1 MeGlc4; 2, 4 Xyl3 & H-1 MeGlc4 \\
\hline 4 & $68.7 \mathrm{CH}$ & $3.90 \mathrm{~m}$ & & \\
\hline \multirow[t]{2}{*}{5} & $65.7 \mathrm{CH}_{2}$ & $4.13 \mathrm{dd}(4.3 ; 11.1)$ & C: 4 Xyl3 & \\
\hline & & $3.60 \mathrm{t}(11.1)$ & C: 1,3 Xyl3 & H-1 Xyl3 \\
\hline \multicolumn{5}{|c|}{ MeGlc4 $(1 \rightarrow 3$ Xyl3) } \\
\hline 1 & $104.4 \mathrm{CH}$ & $5.11 \mathrm{~d}(7.9)$ & C: 3 Xyl3 & $\begin{array}{c}\text { H-3 Xyl3; H-3, } 5 \\
\text { MeGlc4 }\end{array}$ \\
\hline 2 & $74.3 \mathrm{CH}$ & $3.80 \mathrm{t}(7.9)$ & C: 1 MeGlc4 & \\
\hline 3 & $86.4 \mathrm{CH}$ & $3.64 \mathrm{t}(9.1)$ & $\mathrm{C}: 2,4 \mathrm{MeGlc} 4, \mathrm{OMe}$ & H-1, 5 MeGlc4 \\
\hline 4 & $69.7 \mathrm{CH}$ & $3.96 \mathrm{t}(9.1)$ & & \\
\hline 5 & $75.3 \mathrm{CH}$ & $4.03 \mathrm{~m}$ & & H-1, 3 MeGlc4 \\
\hline \multirow[t]{2}{*}{6} & $67.1 \mathrm{CH}_{2}$ & $4.97 \mathrm{dd}(3.0 ; 11.5)$ & C: 5 MeGlc4 & \\
\hline & & $4.71 \mathrm{dd}(6.1 ; 11.5)$ & C: 5 MeGlc 4 & \\
\hline $\mathrm{OMe}$ & $60.5 \mathrm{CH}_{3}$ & $3.76 \mathrm{~s}$ & C: 3 MeGlc4 & \\
\hline
\end{tabular}


Table 1. Cont.

\begin{tabular}{|c|c|c|c|c|}
\hline Atom & $\delta_{C}$ Mult. ${ }^{a-c}$ & $\delta_{\mathrm{H}}$ Mult. $(J \text { in } \mathrm{Hz})^{d}$ & НMBC & ROESY \\
\hline \multicolumn{5}{|c|}{ Glc5 $(1 \rightarrow 4$ Xyl1 $)$} \\
\hline 1 & $102.3 \mathrm{CH}$ & $4.90 \mathrm{~d}(7.9)$ & C: 4 Xyl1 & H-4 Xyl1; H-3, 5 Glc5 \\
\hline 2 & $73.2 \mathrm{CH}$ & $3.84 \mathrm{t}(9.1)$ & C: 1,3 Glc5 & \\
\hline 3 & $86.0 \mathrm{CH}$ & $4.07 \mathrm{t}(9.1)$ & C: 1 MeXyl6; 2 Glc5 & H-1 MeXyl6; H-1 Glc5 \\
\hline 4 & $68.9 \mathrm{CH}$ & $3.88 \mathrm{t}(9.1)$ & & \\
\hline 5 & $75.5 \mathrm{CH}$ & $4.05 \mathrm{~m}$ & & H-1 Glc5 \\
\hline \multirow[t]{2}{*}{6} & $67.1 \mathrm{CH}_{2}$ & $4.97 \mathrm{dd}(1.9 ; 11.5)$ & C: 4,5 Glc5 & \\
\hline & & $4.70 \mathrm{dd}(5.5 ; 11.5)$ & & \\
\hline \multicolumn{5}{|c|}{ MeXyl6 (1 >3Glc5) } \\
\hline 1 & $105.2 \mathrm{CH}$ & $5.07 \mathrm{~d}(7.9)$ & C: 3 Glc5 & H-3 Glc5; H-3,5 MeXyl6 \\
\hline 2 & $74.2 \mathrm{CH}$ & $3.79 \mathrm{t}(8.5)$ & C: 1 MeXyl6 & \\
\hline 3 & $86.6 \mathrm{CH}$ & $3.57 \mathrm{t}(9.1)$ & $\mathrm{C}: 2,4 \mathrm{MeXyl6} ; \mathrm{OMe}$ & H-1 MeXyl6; OMe \\
\hline 4 & $69.9 \mathrm{CH}$ & $3.98 \mathrm{t}(9.1)$ & $\mathrm{C}: 3,5 \mathrm{MeXyl6}$ & \\
\hline \multirow[t]{2}{*}{5} & $66.4 \mathrm{CH}_{2}$ & $4.14 \mathrm{dd}(5.5 ; 12.1)$ & C: 1, 3, 4 MeXyl6 & \\
\hline & & $3.61 \mathrm{t}(11.5)$ & & H-1 MeXyl6 \\
\hline $\mathrm{OMe}$ & $60.5 \mathrm{CH}_{3}$ & $3.79 \mathrm{~s}$ & C: 3 MeXyl6 & H-3 MeXyl6 \\
\hline
\end{tabular}

${ }^{a}$ Recorded at $125.67 \mathrm{MHz}$ in $\mathrm{C}_{5} \mathrm{D}_{5} \mathrm{~N} / \mathrm{D}_{2} \mathrm{O}(4 / 1) .{ }^{b}$ Bold $=$ interglycosidic positions. ${ }^{c}$ Italic $=$ sulfate position. ${ }^{d}$ Recorded at $500.12 \mathrm{MHz}$ in $\mathrm{C}_{5} \mathrm{D}_{5} \mathrm{~N} / \mathrm{D}_{2} \mathrm{O}(4 / 1)$. Multiplicity by $1 \mathrm{D}$ TOCSY. The original spectra of $\mathbf{1}$ are provided in Figures S1-S7.

The (-)ESI-MS/MS of 1 (Figure S8) demonstrated the fragmentation of $\left[\mathrm{M}_{2 \mathrm{Na}}-\mathrm{Na}\right]^{-}$ ion at $m / z 1543.5$ with the ion-peaks observed at $m / z 1423.6\left[\mathrm{M}_{2 \mathrm{Na}}-\mathrm{Na}-\mathrm{NaHSO}_{4}\right]^{-}, 1266.5$ $\left[\mathrm{M}_{2 \mathrm{Na}}-\mathrm{Na}-\mathrm{MeGlcOSO}_{3} \mathrm{Na}+\mathrm{H}\right]^{-}, 1133.5\left[\mathrm{M}_{2 \mathrm{Na}}-\mathrm{Na}-\mathrm{MeGlcOSO}{ }_{3} \mathrm{Na}-\mathrm{Xyl}+\mathrm{H}\right]^{-}, 987.4\left[\mathrm{M}_{2 \mathrm{Na}}{ }^{-}\right.$ $\left.\mathrm{Na}-\mathrm{MeGlcOSO}_{3} \mathrm{Na}-\mathrm{Xyl}-\mathrm{Qui}+\mathrm{H}\right]^{-}, 841.4\left[\mathrm{M}_{2 \mathrm{Na}}-\mathrm{Na}-\mathrm{MeGlCOSO}_{3} \mathrm{Na}-\mathrm{Xyl}--\mathrm{Qui}-\mathrm{MeXyl}+2 \mathrm{H}\right]^{-}$, $665.1 \quad\left[\mathrm{M}_{2 \mathrm{Na}}-\mathrm{Na}-\mathrm{Agl}-\mathrm{MeXyl}-\mathrm{GlcOSO}_{3} \mathrm{Na}+\mathrm{H}\right]^{-}, \quad 533.1 \quad\left[\mathrm{M}_{2 \mathrm{Na}}-\mathrm{Na}-\mathrm{Agl}-\mathrm{MeXyl}-\right.$ $\left.\mathrm{GlcOSO}_{3} \mathrm{Na}-\mathrm{Xyl}+\mathrm{H}\right]^{-}, 387.0\left[\mathrm{M}_{2 \mathrm{Na}}-\mathrm{Na}-\mathrm{Agl}-\mathrm{MeXyl}-\mathrm{GlCOSO}_{3} \mathrm{Na}-\mathrm{Xyl}-\mathrm{Qui}+\mathrm{H}\right]^{-}, 255.0$ $\left[\mathrm{M}_{2 \mathrm{Na}}-\mathrm{Na}-\mathrm{Agl}-\mathrm{MeXyl}-\mathrm{GlCOSO}_{3} \mathrm{Na}-\mathrm{Xyl}-\mathrm{Qui}-\mathrm{Xyl}+\mathrm{H}\right]^{-}$. All these ion peaks corroborated the sequence of monosaccharides and the aglycone structure of $\mathbf{1}$.

Therefore, chitonoidosides E [15] and $\mathrm{E}_{1}$ (1) share the identical oligosaccharide moiety (they belong to the same group of glycosides) and differ from each other through the presence/absence of a carbonyl group at C-18 in the aglycones (the difference of their exact masses by $14 a m u$ in (-) HR-ESI-MS confirmed this). These data indicate that chitonoidoside $\mathrm{E}_{1}(\mathbf{1})$ is $3 \beta$-O-\{6-O-sodium sulfate-3-O-methyl- $\beta$-D-glucopyranosyl- $(1 \rightarrow 3)-\beta$ - $\mathrm{D}$ xylopyranosyl-( $(\rightarrow 4)$ - $\beta$-D-quinovopyranosyl-( $1 \rightarrow 2)$-[3-O-methyl- $\beta$-D-xylopyranosyl-( $1 \rightarrow 3$ )6 -O-sodium sulfate- $\beta$-D-glucopyranosyl-( $1 \rightarrow 4)]-\beta$-D-xylopyranosyl $\}-16$-oxo-holosta-9(11), 25(26)-diene.

The molecular formula of chitonoidoside $\mathrm{F}$ (2) was determined to be $\mathrm{C} 54 \mathrm{H} 82 \mathrm{O} 28 \mathrm{~S}_{2} \mathrm{Na}_{2}$ from the $\left[\mathrm{M}_{2 \mathrm{Na}}-\mathrm{Na}\right]^{-}$ion peak at $\mathrm{m} / z 1265.4337$ (calc. 1265.4337 ) and $\left[\mathrm{M}_{2 \mathrm{Na}}-2 \mathrm{Na}\right]^{2-}$ ion peak at $m / z$ 621.2244 (calc. 621.2269) in the (-)HR-ESI-MS (Figure S16). The 1H NMR spectrum of the carbohydrate part of chitonoidoside $\mathrm{F}(2)$ exhibited four characteristic doublets at $\delta_{\mathrm{H}} 4.67-5.18(J=7.6-8.1 \mathrm{~Hz})$, correlated by the HSQC spectrum with corresponding anomeric carbon signals at $\delta_{C} 102.2-104.9$. These signals were indicative of a tetrasaccharide chain with $\beta$-configurations of glycosidic bonds (Table 2, Figures S9-S15).

An isolated spin system from each monosaccharide residue was analyzed using the ${ }^{1} \mathrm{H},{ }^{1} \mathrm{H}-\mathrm{COSY}$ and 1D TOCSY spectra. Further analysis of the HSQC, ROESY and HMBC spectra resulted in the assignment of all monosaccharide NMR signals. Using this algorithm, the monosaccharides composing the carbohydrate moiety of chitonoidoside $F(2)$ were found to be xylose (Xyl1), quinovose (Qui2), glucose (Glc3), and 3-O-methylglucose (MeGlc4). The monosaccharide compositions of the other glycosides, reported herein, were established in the same manner. 
Table 2. ${ }^{13} \mathrm{C}$ and ${ }^{1} \mathrm{H}$ NMR chemical shifts, HMBC and ROESY correlations of carbohydrate moiety of chitonoidoside $\mathrm{F}(2)$.

\begin{tabular}{|c|c|c|c|c|}
\hline Atom & $\delta_{C}$ Mult. ${ }^{a-c}$ & $\delta_{\mathrm{H}}$ Mult. $(J \text { in } \mathrm{Hz})^{d}$ & НМВС & ROESY \\
\hline \multicolumn{5}{|c|}{ Xyl1 $(1 \rightarrow C-3)$} \\
\hline 1 & $104.8 \mathrm{CH}$ & $4.67 \mathrm{~d}(7.6)$ & $C: 3$ & H-3; H-3, 5 Xyl1 \\
\hline 2 & $82.1 \mathrm{CH}$ & $3.98 \mathrm{t}(8.3)$ & C: 1 Qui2; 3 Xyl1 & H-1 Qui2 \\
\hline 3 & $75.1 \mathrm{CH}$ & $4.17 \mathrm{t}(8.3)$ & C: 4 Xyl1 & \\
\hline 4 & $78.0 \mathrm{CH}$ & $4.16 \mathrm{~m}$ & & H-1 Xyl1; H-1 Glc3 \\
\hline \multirow[t]{2}{*}{5} & $63.5 \mathrm{CH}_{2}$ & $4.38 \mathrm{~d}(10.2)$ & & \\
\hline & & $3.63 \mathrm{~m}$ & & H-1, 3 Xyl1 \\
\hline \multicolumn{5}{|c|}{ Qui2 $(1 \rightarrow 2$ Xyl1) } \\
\hline 1 & $104.9 \mathrm{CH}$ & $5.06 \mathrm{~d}(8.1)$ & C: 2 Xyl1 & H-2 Xyl1; H-3, 5 Qui2 \\
\hline 2 & $76.2 \mathrm{CH}$ & $3.88 \mathrm{t}(9.1)$ & C: 1 Qui2 & H-4 Qui2 \\
\hline 3 & $76.8 \mathrm{CH}$ & $4.06 \mathrm{t}(9.1)$ & C: 2, 4 Qui2 & H-1, 5 Qui2 \\
\hline 4 & $76.2 \mathrm{CH}$ & 3.58 t (9.1) & C: 3, 5 Qui2 & H-2 Qui2 \\
\hline 5 & $72.8 \mathrm{CH}$ & 3.70 dd $(6.3 ; 9.9)$ & C: 4 Qui2 & H-1, 3 Qui2 \\
\hline 6 & $18.2 \mathrm{CH}_{3}$ & $1.53 \mathrm{~d}(6.3)$ & C: 4, 5 Qui2 & \\
\hline \multicolumn{5}{|c|}{ Glc3 $(1 \rightarrow 4$ Xyl1 $)$} \\
\hline 1 & $102.2 \mathrm{CH}$ & $4.90 \mathrm{~d}(8.0)$ & C: 4 Xyl1 & H-4 Xyl1; H-3, 5 Glc3 \\
\hline 2 & $73.3 \mathrm{CH}$ & 3.83 t (9.2) & C: 1 Glc3 & \\
\hline 3 & $86.0 \mathrm{CH}$ & $4.17 \mathrm{t}(9.2)$ & C: 2, 4 Glc3; 1 MeGlc4 & H-1 MeGlc4; H-1 Glc3 \\
\hline 4 & $68.9 \mathrm{CH}$ & 3.87 t (9.2) & C: 5 Glc3 & \\
\hline 5 & $75.1 \mathrm{CH}$ & $4.04 \mathrm{~m}$ & & H-1 Glc3 \\
\hline \multirow[t]{2}{*}{6} & $67.2 \mathrm{CH}_{2}$ & $4.94 \mathrm{~d}(10.3)$ & & \\
\hline & & $4.68 \mathrm{~m}$ & & \\
\hline \multicolumn{5}{|c|}{ MeGlc4 (1 $\rightarrow$ 3Glc3) } \\
\hline 1 & $104.3 \mathrm{CH}$ & $5.18 \mathrm{~d}(8.0)$ & C: 3 Glc3 & $\begin{array}{c}\text { H-3 Glc3; H-3, } 5 \\
\text { MeGlc4 }\end{array}$ \\
\hline 2 & $74.0 \mathrm{CH}$ & 3.86 t (8.7) & C: 1,3 MeGlc4 & H-4 MeGlc4 \\
\hline 3 & $85.3 \mathrm{CH}$ & $3.71 \mathrm{t}(8.7)$ & $\mathrm{C}: 4,5 \mathrm{MeGlc} 4, \mathrm{OMe}$ & H-1, 5 MeGlc4; Ome \\
\hline 4 & $76.3 \mathrm{CH}$ & 4.88 t (9.6) & C: 3, 5 MeGlc4 & H-2 MeGlc4 \\
\hline 5 & $76.4 \mathrm{CH}$ & 3.86 t (8.7) & & H-1 MeGlc4 \\
\hline \multirow[t]{2}{*}{6} & $61.2 \mathrm{CH}_{2}$ & $4.51 \mathrm{~d}(11.4)$ & & \\
\hline & & $4.33 \mathrm{dd}(4.4 ; 11.4)$ & & \\
\hline $\mathrm{OMe}$ & $60.7 \mathrm{CH}_{3}$ & $3.93 \mathrm{~s}$ & C: 3 MeGlc4 & \\
\hline
\end{tabular}

${ }^{a}$ Recorded at $125.67 \mathrm{MHz}$ in $\mathrm{C}_{5} \mathrm{D}_{5} \mathrm{~N} / \mathrm{D}_{2} \mathrm{O}(4 / 1) .{ }^{b}$ Bold $=$ interglycosidic positions. ${ }^{c}$ Italic $=$ sulfate position. ${ }^{d}$ Recorded at $500.12 \mathrm{MHz}$ in $\mathrm{C}_{5} \mathrm{D}_{5} \mathrm{~N} / \mathrm{D}_{2} \mathrm{O}(4 / 1)$. Multiplicity by 1D TOCSY. The original spectra of 2 are provided in Figures S9-S15.

The signal of C-6 Glc3 in the ${ }^{13} \mathrm{C}$ NMR spectrum of 2 was deshielded to $\delta_{C} 67.2$, which is characteristic of sulfation at this position. The signal of C-6 MeGlc4 was observed at $\delta_{C} 61.2$, indicating the absence of a sulfate group at this position, although the MS data indicated the presence of two sulfate groups in 2. The signal of C-4 MeGlc4 was deshielded to $\delta_{\mathrm{C}} 76.3$ when compared to the same signal of terminal 3-O-methylglucose residues of the glycosides lacking a sulfate group $\left(\delta_{C} \sim 70.0\right)$ [12]. Moreover, the signals of C-3 and C-5 MeGlc4 in the spectrum of 2 were shielded to $\delta_{C} 85.3$ and 76.4, respectively, due to the $\beta$-shifting effect of a sulfate group. Therefore, the 3-O-methylglucose residue in the sugar part of 2 was sulfated by C-4. This structural feature was only found once in previous research-in the glycosides of Colochirus quadrangularis [17]. The observation of 3-O-methylxylose residue sulfated by C-4 in the glycosides of $P$. chitonoides [15] clearly demonstrates the presence of a specific sulfatase capable of attaching a sulfate group to $\mathrm{C}-4$ of monosaccharides in pyranose form.

The positions of glycosidic linkages, established by the ROESY and HMBC spectra of 2 revealed the uncommon architecture of the sugar chain with disaccharide fragment 4-O-sodium sulfate-3-O-methyl- $\beta$-D-glucopyranosyl- $(1 \rightarrow 3)$-6-O-sodium sulfate- $\beta$-Dglucopyranosyl- $(1 \rightarrow 4)$ attached to the first $(X y 11)$ residue, while quinovose was a terminal unit in the reduced bottom semi-chain (Table 2). Two tetraosides whose carbohydrate part featured the same architecture were found only in the sea cucumber Thyonidium kurilensis [18]. 
The (-)ESI-MS/MS of 2 (Figure S16) demonstrated the fragmentation of $\left[\mathrm{M}_{2 \mathrm{Na}}-\mathrm{Na}\right]^{-}$ ion at $m / z 1265.4$ resulting in the ion-peaks appearance at $m / z 1146.5\left[\mathrm{M}_{2 \mathrm{Na}}-\mathrm{Na}-\mathrm{NaSO}_{4}\right]^{-}$, $987.4\left[\mathrm{M}_{2 \mathrm{Na}}-\mathrm{Na}-\mathrm{MeGlcOSO} 3 \mathrm{Na}+\mathrm{H}\right]^{-}$, , 841.4, $\left[\mathrm{M}_{2 \mathrm{Na}}-\mathrm{Na}-\mathrm{MeGlcOSO}_{3} \mathrm{Na}-\text { Qui) }+\mathrm{H}\right]^{-}$, corroborating the notion that sulfated 3-O-methylglucose and quinovose are terminal monosaccharides. All these data indicate that chitonoidoside $\mathrm{F}(2)$ is $3 \beta-O-\{\beta$-D-quinovopyranosyl$(1 \rightarrow 2)$-(4-O-sodium sulfate-3-O-methyl- $\beta$-D-glucopyranosyl-( $1 \rightarrow 3)$-6-O-sodium sulfate- $\beta$ D-glucopyranosyl-(1 $\rightarrow 4))$ - $\beta$-D-xylopyranosyl\}-16-oxo-holosta-9(11),25(26)-diene.

The molecular formula of chitonoidoside $\mathrm{G}$ (3) was determined to be $\mathrm{C}_{66} \mathrm{H}_{104} \mathrm{O}_{36} \mathrm{~S}_{2} \mathrm{Na}_{2}$ from the $\left[\mathrm{M}_{2 \mathrm{Na}}-\mathrm{Na}\right]^{-}$ion peak at $\mathrm{m} / z 1559.5646$ (calc. 1559.5652 ) and $\left[\mathrm{M}_{2 \mathrm{Na}}-2 \mathrm{Na}\right]^{2-}$ ion peak at $m / z 768.2895$ (calc. 768.2880) in the (-)HR-ESI-MS (Figure S24).

Based on the absence of the signals of 18(20)-lactone at $\delta_{\mathrm{C}} \sim 178(\mathrm{C}-18)$ and $\sim 83(\mathrm{C}-20)$ in the ${ }^{13} \mathrm{C}$ NMR spectrum of 3, the aglycone with 18(20)-ether bond instead of the lactone was supposed to be present. The NMR spectra of the aglycone part of chitonoidosides G (3) and A [15], where this aglycone was first found, were almost coincident with each other (Table 3, Figures S17-S22).

Table 3. ${ }^{13} \mathrm{C}$ and ${ }^{1} \mathrm{H}$ NMR chemical shifts, HMBC and ROESY correlations of the aglycone moiety of chitonoidoside G (3).

\begin{tabular}{|c|c|c|c|c|}
\hline Position & $\delta_{\mathrm{C}}$ Mult. $^{a}$ & $\delta_{\mathrm{H}}$ Mult. $(J \text { in } \mathrm{Hz})^{b}$ & НМВС & ROESY \\
\hline 1 & $35.9 \mathrm{CH}_{2}$ & $1.60 \mathrm{~m}$ & & H-11 \\
\hline \multirow[t]{2}{*}{2} & $26.7 \mathrm{CH}_{2}$ & $2.08 \mathrm{~m}$ & & \\
\hline & & $1.83 \mathrm{~m}$ & & H-19, H-30 \\
\hline 3 & $88.7 \mathrm{CH}$ & $3.12 \mathrm{dd}(4.2 ; 11.8)$ & C: 1 Xyl1 & H-5, H-31, H1-Xyl1 \\
\hline 4 & $39.6 \mathrm{C}$ & & & \\
\hline 5 & $52.7 \mathrm{CH}$ & 0.75 brd (12.0) & C: 10,19 & H-3, H-31 \\
\hline \multirow[t]{2}{*}{6} & $20.9 \mathrm{CH}_{2}$ & $1.57 \mathrm{~m}$ & & H-31 \\
\hline & & $1.35 \mathrm{~m}$ & & H-19, H-30 \\
\hline \multirow[t]{2}{*}{7} & $28.7 \mathrm{CH}_{2}$ & $1.57 \mathrm{~m}$ & & \\
\hline & & $1.17 \mathrm{~m}$ & & \\
\hline 8 & $40.9 \mathrm{CH}$ & $2.31 \mathrm{~m}$ & & H-18, H-19 \\
\hline 9 & $150.9 \mathrm{C}$ & & & \\
\hline 10 & $39.5 \mathrm{C}$ & & & \\
\hline 11 & $114.7 \mathrm{CH}$ & $5.30 \mathrm{~m}$ & & $\mathrm{H}-1$ \\
\hline \multirow{2}{*}{12} & $33.8 \mathrm{CH}_{2}$ & $2.38 \mathrm{~m}$ & & H-32 \\
\hline & & $2.25 \mathrm{~m}$ & & $\mathrm{H}-21$ \\
\hline 13 & $56.3 \mathrm{C}$ & & & \\
\hline 14 & $40.3 \mathrm{C}$ & & & \\
\hline \multirow[t]{2}{*}{15} & $50.5 \mathrm{CH}_{2}$ & $2.47 \mathrm{~d}(15.9)$ & C: $14,16,32$ & H-18 \\
\hline & & $2.19 \mathrm{~d}(15.9)$ & C: 13,16 & H-32 \\
\hline 16 & $218.1 \mathrm{C}$ & & & \\
\hline 17 & $63.8 \mathrm{CH}$ & $2.35 \mathrm{~s}$ & C: $12,13,16,18,20,21$ & H-12, H-21, H-22, H-32 \\
\hline \multirow[t]{2}{*}{18} & $73.8 \mathrm{CH}_{2}$ & $4.02 \mathrm{~m}$ & & \\
\hline & & $3.65 \mathrm{~d}(9.1)$ & $C: 12,20$ & \\
\hline 19 & $22.2 \mathrm{CH}_{3}$ & $0.97 \mathrm{~s}$ & $C: 1,5,9,10$ & $\mathrm{H}-1, \mathrm{H}-2, \mathrm{H}-6, \mathrm{H}-8, \mathrm{H}-18$ \\
\hline 20 & $86.6 \mathrm{C}$ & & & \\
\hline 21 & $26.1 \mathrm{CH}_{3}$ & $1.32 \mathrm{~s}$ & C: $17,20,22$ & H-12, H-17, H-18, H-22 \\
\hline \multirow[t]{2}{*}{22} & $37.8 \mathrm{CH}_{2}$ & $1.70 \mathrm{~m}$ & & \\
\hline & & $1.57 \mathrm{~m}$ & & $\mathrm{H}-21, \mathrm{H}-24$ \\
\hline \multirow[t]{2}{*}{23} & $22.7 \mathrm{CH}_{2}$ & $1.69 \mathrm{~m}$ & & \\
\hline & & $1.56 \mathrm{~m}$ & & \\
\hline 24 & $38.2 \mathrm{CH}_{2}$ & $1.95 \mathrm{~m}$ & C: 23 & $\mathrm{H}-21$ \\
\hline 25 & $146.0 \mathrm{C}$ & & & \\
\hline \multirow[t]{2}{*}{26} & $110.2 \mathrm{CH}_{2}$ & 4.72 brs & C: 24,27 & \\
\hline & & $4.71 \mathrm{brs}$ & C: 24,27 & \\
\hline 27 & $22.2 \mathrm{CH}_{3}$ & $1.65 \mathrm{~s}$ & C: $24,25,26$ & $\mathrm{H}-24$ \\
\hline 30 & $16.5 \mathrm{CH}_{3}$ & $0.97 \mathrm{~s}$ & C: $3,4,5,31$ & H-31 \\
\hline 31 & $27.9 \mathrm{CH}_{3}$ & $1.13 \mathrm{~s}$ & $C: 3,4,5,30$ & H-1, H-3, H-5, H-30 \\
\hline 32 & $21.4 \mathrm{CH}_{3}$ & $0.78 \mathrm{~s}$ & C: $13,14,15$ & H-15, H-17 \\
\hline
\end{tabular}

${ }^{a}$ Recorded at $125.67 \mathrm{MHz}$ in $\mathrm{C}_{5} \mathrm{D}_{5} \mathrm{~N} / \mathrm{D}_{2} \mathrm{O}(4 / 1) .{ }^{b}$ Recorded at $500.12 \mathrm{MHz}$ in $\mathrm{C}_{5} \mathrm{D}_{5} \mathrm{~N} / \mathrm{D}_{2} \mathrm{O}(4 / 1)$. The original spectra of 3 are provided in Figures S17-S23.

The ${ }^{1} \mathrm{H}$ and ${ }^{13} \mathrm{C}$ NMR spectra of the carbohydrate chain of chitonoidoside $\mathrm{G}$ (3) (Table 4, Figures S17-S23) demonstrated six signals of anomeric protons at $\delta_{\mathrm{H}} 4.66-5.18$ $(\mathrm{d}, J=6.9-7.9 \mathrm{~Hz})$, corresponding to the signals of the anomeric carbons at $\delta_{\mathrm{C}} 102.2-104.8$. 
These signals indicated the presence of a hexasaccharide moiety with $\beta$-glycosidic bonds. The monosaccharide composition of $\mathbf{3}$ was determined as two xyloses (Xyl1 and Xyl3), quinovose (Qui2), glucose (Glc5), and two 3-O-methylglucoses (MeGlc4 and MeGlc6). The doubled signal at $\delta_{C} 67.1$ indicated the presence of two sulfate groups. Using the $1 \mathrm{H}, 1 \mathrm{H}-$ COSY and 1D TOCSY spectra their positions were deduced as C-6 MeGlc4 and C-6 Glc5. The comparison of the ${ }^{13} \mathrm{C}$ NMR spectra of the carbohydrate parts of the chitonoidosides $\mathrm{G}(\mathbf{3})$ and $\mathrm{E}_{1}$ (1) demonstrated the closeness of the signals of the monosaccharide units from first to fifth. The signals of the terminal sixth monosaccharide residue in $\mathbf{3}$ were assigned as 3-O-methylglucose instead of 3-O-methylxylose in $\mathbf{1}$. The sequence of monosaccharides and the positions of the glycosidic bonds were confirmed by the correlations in the ROESY and HMBC spectra of $\mathbf{3}$ (Table 4, Figures S17-S23). Therefore, chitonoidoside G (3) is the first compound in the combinatorial library of the glycosides from P. chitonoides to feature non-sulfated 3-O-methylglucose as terminal residue in the upper semi-chain.

Table 4. ${ }^{13} \mathrm{C}$ and ${ }^{1} \mathrm{H}$ NMR chemical shifts, HMBC and ROESY correlations of carbohydrate moiety of chitonoidoside G (3).

\begin{tabular}{|c|c|c|c|c|}
\hline Atom & $\delta_{C}$ Mult. ${ }^{a-c}$ & $\delta_{\mathrm{H}}$ Mult. $(J \text { in } \mathrm{Hz})^{d}$ & HMBC & ROESY \\
\hline \multicolumn{5}{|c|}{ Xyl1 $(1 \rightarrow C-3)$} \\
\hline 1 & $104.8 \mathrm{CH}$ & $4.66 \mathrm{~d}(6.9)$ & $C: 3$ & H-3; H-3, 5 Xyl1 \\
\hline 2 & $82.1 \mathrm{CH}$ & $3.97 \mathrm{t}(8.8)$ & C: 1 Qui2; 1, 3 Xyl1 & H-1 Qui2 \\
\hline 3 & $75.1 \mathrm{CH}$ & $4.16 \mathrm{t}(8.8)$ & C: 4 Xyl1 & \\
\hline 4 & $77.8 \mathrm{CH}$ & $4.16 \mathrm{~m}$ & & \\
\hline \multirow[t]{2}{*}{5} & $63.5 \mathrm{CH}_{2}$ & $4.37 \mathrm{dd}(4.1 ; 11.8)$ & & \\
\hline & & $3.62 \mathrm{~m}$ & & H-1 Xyl1 \\
\hline \multicolumn{5}{|c|}{ Qui2 (1 $\rightarrow 2$ Xyl1) } \\
\hline 1 & $104.5 \mathrm{CH}$ & $5.04 \mathrm{~d}(7.3)$ & C: 2 Xyl1 & H-2 Xyl1; H-3, 5 Qui2 \\
\hline 2 & $75.7 \mathrm{CH}$ & $3.87 \mathrm{t}(9.0)$ & C: 1,3 Qui2 & H-4 Qui2 \\
\hline 3 & $74.8 \mathrm{CH}$ & 3.98 t $(9.0)$ & C: 2, 4 Qui2 & H-5 Qui2 \\
\hline 4 & $85.6 \mathrm{CH}$ & $3.49 \mathrm{t}(9.0)$ & C: 1 Xyl3; 3, 5 Qui2 & H-1 Xyl3; H-2 Qui2 \\
\hline 5 & $71.4 \mathrm{CH}$ & $3.68 \mathrm{dd}(6.2 ; 9.0)$ & & H-1 Qui2 \\
\hline 6 & $17.8 \mathrm{CH}_{3}$ & $1.62 \mathrm{~d}(6.2)$ & C: 4, 5 Qui2 & $\mathrm{H}-4,5$ Qui2 \\
\hline \multicolumn{5}{|c|}{ Xyl3 (1 $\rightarrow$ 4Qui2) } \\
\hline 1 & $104.4 \mathrm{CH}$ & $4.75 \mathrm{~d}(7.7)$ & C: 4 Qui2 & H-4 Qui2; H-3, 5 Xyl3 \\
\hline 2 & $73.2 \mathrm{CH}$ & $3.84 \mathrm{t}(8.3)$ & C: 1,3 Xyl3 & \\
\hline 3 & $87.0 \mathrm{CH}$ & $4.04 \mathrm{t}(8.3)$ & C: 1 MeGlc4; 2, 4 Xyl3 & H-1 MeGlc4; H-1 Xyl3 \\
\hline 4 & $68.8 \mathrm{CH}$ & $3.89 \mathrm{~m}$ & C: 5 Xyl3 & \\
\hline \multirow[t]{2}{*}{5} & $65.7 \mathrm{CH}_{2}$ & $4.12 \mathrm{dd}(5.3 ; 11.2)$ & & \\
\hline & & $3.59 \mathrm{~d}(11.2)$ & C: 1 Xyl3 & H-1 Xyl3 \\
\hline \multicolumn{5}{|c|}{ MeGlc4 (1 $\rightarrow 3$ Xyl3) } \\
\hline 1 & $104.6 \mathrm{CH}$ & $5.12 \mathrm{~d}(7.9)$ & C: 3 Xyl3 & $\begin{array}{c}\text { H-3 Xyl3; H-3, } 5 \\
\text { MeGlc4 }\end{array}$ \\
\hline 2 & $74.3 \mathrm{CH}$ & $3.80 \mathrm{t}(8.5)$ & C: 1 MeGlc4 & \\
\hline 3 & $86.4 \mathrm{CH}$ & $3.64 \mathrm{t}(8.5)$ & C: 4 MeGlc4, OMe & H-1 MeGlc4; OMe \\
\hline 4 & $69.9 \mathrm{CH}$ & $3.96 \mathrm{t}(8.5)$ & C: $3,5,6$ MeGlc4 & H-2, 6 MeGlc4 \\
\hline 5 & $75.5 \mathrm{CH}$ & $4.03 \mathrm{~m}$ & & H-1, 3 MeGlc4 \\
\hline \multirow[t]{2}{*}{6} & $67.1 \mathrm{CH}_{2}$ & $4.97 \mathrm{~d}(10.7)$ & & \\
\hline & & $4.71 \mathrm{dd}(5.6 ; 11.3)$ & C: 5 MeGlc4 & \\
\hline $\mathrm{OMe}$ & $60.5 \mathrm{CH}_{3}$ & $3.76 \mathrm{~s}$ & C: 3 MeGlc4 & \\
\hline \multicolumn{5}{|c|}{ Glc5 $(1 \rightarrow 4$ Xyl1) } \\
\hline 1 & $102.2 \mathrm{CH}$ & $4.88 \mathrm{~d}(7.9)$ & C: 4 Xyl1 & H-4 Xyl1; H-3, 5 Glc5 \\
\hline 2 & $73.2 \mathrm{CH}$ & $3.84 \mathrm{t}(9.0)$ & C: 1,3 Glc5 & \\
\hline 3 & 86.0 CH & $4.16 \mathrm{t}(9.0)$ & C: 1 MeGlc6; 2 Glc5 & H-1 MeGlc6; H-1 Glc5 \\
\hline 4 & $69.0 \mathrm{CH}$ & 3.89 t $(9.0)$ & C: 3 Glc5 & \\
\hline 5 & $75.5 \mathrm{CH}$ & $4.02 \mathrm{~m}$ & & H-1 Glc5 \\
\hline \multirow[t]{2}{*}{6} & $67.1 \mathrm{CH}_{2}$ & $4.93 \mathrm{~d}(10.7)$ & & \\
\hline & & $4.68 \mathrm{dd}(6.2 ; 11.3)$ & & \\
\hline
\end{tabular}


Table 4. Cont.

\begin{tabular}{|c|c|c|c|c|}
\hline Atom & $\delta_{C}$ Mult. $^{a-c}$ & $\delta_{\mathrm{H}}$ Mult. $(J \text { in } \mathrm{Hz})^{d}$ & НМBC & ROESY \\
\hline \multicolumn{5}{|c|}{ MeGlc6 $(1 \rightarrow 3$ Glc5) } \\
\hline 1 & $104.4 \mathrm{CH}$ & $5.18 \mathrm{~d}(7.5)$ & C: 3 Glc5 & $\begin{array}{c}\text { H-3 Glc5; H-3, } 5 \\
\text { MeGlc6 }\end{array}$ \\
\hline 2 & $74.5 \mathrm{CH}$ & $3.84 \mathrm{t}(8.8)$ & C: 1 MeGlc6 & \\
\hline 3 & $86.8 \mathrm{CH}$ & $3.66 \mathrm{t}(8.8)$ & C: 2, 4 MeGlc6, OMe & H-1 MeGlc6 \\
\hline 4 & $70.3 \mathrm{CH}$ & $3.89 \mathrm{~m}$ & C: 5 MeGlc6 & H-6 MeGlc6 \\
\hline 5 & $77.5 \mathrm{CH}$ & $3.89 \mathrm{~m}$ & & H-1 MeGlc6 \\
\hline \multirow[t]{2}{*}{6} & $61.7 \mathrm{CH}_{2}$ & $4.34 \mathrm{dd}(2.2 ; 11.7)$ & & \\
\hline & & $4.05 \mathrm{dd}(5.1 ; 11.7)$ & C: 4 MeGlc6 & \\
\hline $\mathrm{OMe}$ & $60.6 \mathrm{CH}_{3}$ & $3.80 \mathrm{~s}$ & C: 3 MeGlc6 & \\
\hline
\end{tabular}

${ }^{a}$ Recorded at $125.67 \mathrm{MHz}$ in $\mathrm{C}_{5} \mathrm{D}_{5} \mathrm{~N} / \mathrm{D}_{2} \mathrm{O}(4 / 1) .{ }^{b}$ Bold $=$ interglycosidic positions. ${ }^{c}$ Italic $=$ sulfate position. ${ }^{d}$ Recorded at $500.12 \mathrm{MHz}$ in $\mathrm{C}_{5} \mathrm{D}_{5} \mathrm{~N} / \mathrm{D}_{2} \mathrm{O}(4 / 1)$. Multiplicity by $1 \mathrm{D}$ TOCSY. The original spectra of $\mathbf{1}$ are provided in Figures S17-S23.

The (-)ESI-MS/MS of 3 (Figure S24) demonstrated the fragmentation of $\left[\mathrm{M}_{2 \mathrm{Na}}-\mathrm{Na}\right]^{-}$ ion at $m / z 1559.6$ leading to the ion-peaks appearance at $m / z 1439.6\left[\mathrm{M}_{2 \mathrm{Na}}-\mathrm{Na}-\mathrm{NaHSO}_{4}\right]^{-}$, $1383.6\left[\mathrm{M}_{2 \mathrm{Na}}-\mathrm{Na}-\mathrm{MeGlc}+\mathrm{H}\right]^{-}, 1281.6\left[\mathrm{M}_{2 \mathrm{Na}}-\mathrm{Na}-\mathrm{MeGlcOSO}_{3} \mathrm{Na}+\mathrm{H}\right]^{-}, 1149.5\left[\mathrm{M}_{2 \mathrm{Na}}{ }^{-}\right.$ $\left.\mathrm{Na}-\mathrm{MeGlcOSO}_{3} \mathrm{Na}-\mathrm{Xyl}+\mathrm{H}\right]^{-}, 1003.5\left[\mathrm{M}_{2 \mathrm{Na}}-\mathrm{Na}-\mathrm{MeGlcOSO}_{3} \mathrm{Na}-\mathrm{Xyl}-\mathrm{Qui}+\mathrm{H}\right]^{-}, 533.1$ $\left[\mathrm{M}_{2 \mathrm{Na}}-\mathrm{Na}-\mathrm{Agl}-\mathrm{MeGlc}-\mathrm{MeGlcOSO}{ }_{3} \mathrm{Na}-\mathrm{Xyl}+\mathrm{H}\right]^{-}, \quad 387.0 \quad\left[\mathrm{M}_{2 \mathrm{Na}}-\mathrm{Na}-\mathrm{Agl}-\mathrm{MeGlc}-\right.$ $\left.\mathrm{MeGlcOSO}_{3} \mathrm{Na}-\mathrm{Xyl}-\mathrm{Qui}+\mathrm{H}\right]^{-}$, $255.0\left[\mathrm{M}_{2 \mathrm{Na}}-\mathrm{Na}-\mathrm{Agl}-\mathrm{MeGlc}-\mathrm{MeGlcOSO}_{3} \mathrm{Na}-\mathrm{Xyl}-\right.$ Qui- $\mathrm{Xyl}+\mathrm{H}]^{-}$, confirming the sequence of monosaccharides and the aglycone structure of 3.

These data indicate that chitonoidoside $\mathrm{G}(3)$ is $3 \beta-O-\{6-O$-sodium sulfate-3-O-methyl$\beta$-D-glucopyranosyl-( $1 \rightarrow 3)-\beta$-D-xylopyranosyl-( $1 \rightarrow 4)$ - $\beta$-D-quinovopyranosyl- $(1 \rightarrow 2)$-[3-Omethyl- $\beta$-D-glucopyranosyl-( $1 \rightarrow 3)$-6-O-sodium sulfate- $\beta$-D-glucopyranosyl-( $(1 \rightarrow 4)]-\beta$-Dxylopyranosyl\}-16-oxo-18(20)-epoxylanosta-9(11),25(26)-diene.

The molecular formula of chitonoidoside $\mathrm{H}(4)$ was determined to be $\mathrm{C}_{59} \mathrm{H}_{90} \mathrm{O}_{32} \mathrm{~S}_{2} \mathrm{Na}_{2}$ from the $\left[\mathrm{M}_{2 \mathrm{Na}}-\mathrm{Na}\right]^{-}$ion peak at $m / z 1397.4749$ (calc. 1397.4760) and $\left[\mathrm{M}_{2 \mathrm{Na}}-2 \mathrm{Na}\right]^{2-}$ ion peak at $\mathrm{m} / \mathrm{z} 687.2442$ (calc. 687.2434) in the (-)HR-ESI-MS (Figure S33).

The ${ }^{1} \mathrm{H}$ and ${ }^{13} \mathrm{C}$ NMR spectra of the carbohydrate chain of chitonoidoside $\mathrm{H}$ (4) (Table 5, Figures S25-S32) demonstrated five signals of anomeric protons at $\delta_{\mathrm{H}} 4.66-5.18$ $(\mathrm{d}, J=6.9-8.1 \mathrm{~Hz})$, corresponding to the signals of the anomeric carbons at $\delta_{\mathrm{C}} 102.3-104.8$, which indicated the presence of a pentasaccharide oligosaccharide chain with $\beta$-glycosidic bonds between the monosaccharides. The analysis of the 1H,1H-COSY, 1D, and 2D TOCSY and HSQC spectra resulted in the assignment of the signals of two xyloses (Xyl1 and Xyl3), quinovose (Qui2), glucose (Glc4), and 3-O-methylglucose (MeGlc5). One sulfate group in chitonoidoside $\mathrm{H}$ (4) was attached to C-6 Glc4 (in the upper semi-chain), which is a typical position for chitonoidosides that feature a branch point in the sugar chain at $\mathrm{C}-4 \mathrm{Xyl1}$, with the exception of chitonoidoside B [15], containing one sulfate group. The position of the second sulfate group was determined as $\mathrm{C}-4$ MeGlc5, based on the deshielding of the signal of $\mathrm{C}-4 \mathrm{MeGlc} 5$ to $\delta_{\mathrm{C}} 76.2$ ( $\alpha$-shifting effect of sulfate group) and the shielding of the signals C-3 and C-5 MeGlc5 to $\delta_{C} 85.2$ and 76.4 ( $\beta$-shifting effect of sulfate group), respectively, compared to the signals in the chitonoidoside $G(3)$. The sequence of the monosaccharides and the positions of the glycosidic bonds deduced by the ROESY and HMBC spectra of 4 displayed the bottom semi-chain, composed of two monosaccharide units, and the upper semi-chain, composed of three monosaccharide units, forming a chain with an uncommon architecture (Table 5, Figures S25-S32). 
Table 5. ${ }^{13} \mathrm{C}$ and ${ }^{1} \mathrm{H}$ NMR chemical shifts, HMBC and ROESY correlations of carbohydrate moiety of chitonoidoside $\mathrm{H}$ (4).

\begin{tabular}{|c|c|c|c|c|}
\hline Atom & $\delta_{C}$ Mult. ${ }^{a-c}$ & $\delta_{\mathrm{H}}$ Mult. $(J \text { in } \mathrm{Hz})^{d}$ & HМBC & ROESY \\
\hline \multicolumn{5}{|c|}{ Xyl1 $(1 \rightarrow C-3)$} \\
\hline 1 & $104.6 \mathrm{CH}$ & $4.66 \mathrm{~d}(6.9)$ & $C: 3$ & H-3; H-3, 5 Xyl1 \\
\hline 2 & $81.9 \mathrm{CH}$ & $3.97 \mathrm{~m}$ & C: 1 Qui2; 1 Xyl1 & H-1 Qui2 \\
\hline 3 & $75.1 \mathrm{CH}$ & $4.16 \mathrm{~m}$ & C: 4 Xyl1 & H-1 Xyl1 \\
\hline 4 & $78.0 \mathrm{CH}$ & $4.15 \mathrm{~m}$ & & H-1 Glc4 \\
\hline \multirow[t]{2}{*}{5} & $63.5 \mathrm{CH}_{2}$ & $4.38 \mathrm{~m}$ & C: 3 Xyl1 & \\
\hline & & $3.62 \mathrm{~m}$ & & H-1 Xyl1 \\
\hline \multicolumn{5}{|c|}{ Qui2 $(1 \rightarrow 2$ Xyl1) } \\
\hline 1 & $104.4 \mathrm{CH}$ & $5.07 \mathrm{~d}(6.9)$ & C: 2 Xyl1 & H-2 Xyl1; H-5 Qui2 \\
\hline 2 & $75.7 \mathrm{CH}$ & $3.87 \mathrm{t}(9.2)$ & C: 1, 3 Qui2 & H-4 Qui2 \\
\hline 3 & $74.8 \mathrm{CH}$ & $4.00 \mathrm{t}(9.2)$ & C: 2, 4 Qui2 & H-1 Qui2 \\
\hline 4 & $85.6 \mathrm{CH}$ & $3.47 \mathrm{t}(9.2)$ & C: 1 Xyl3; 3, 5 Qui2 & H-1 Xyl3; H-2 Qui2 \\
\hline 5 & $71.4 \mathrm{CH}$ & $3.70 \mathrm{dd}(6.2 ; 9.2)$ & & H-1, 3 Qui2 \\
\hline 6 & $17.8 \mathrm{CH}_{3}$ & $1.61 \mathrm{~d}(6.2)$ & C: 4, 5 Qui2 & H-4, 5 Qui2 \\
\hline \multicolumn{5}{|c|}{ Xyl3 (1 $\rightarrow$ 4Qui2) } \\
\hline 1 & $104.8 \mathrm{CH}$ & $4.70 \mathrm{~d}(6.6)$ & C: 4 Qui2 & H-4 Qui2; H-3, 5 Xyl3 \\
\hline 2 & $73.3 \mathrm{CH}$ & $3.82 \mathrm{t}(8.4)$ & C: 1,3 Xyl3 & \\
\hline 3 & $77.2 \mathrm{CH}$ & $4.05 \mathrm{t}(8.4)$ & C: 2,4 Xyl3 & \\
\hline 4 & $70.1 \mathrm{CH}$ & $4.03 \mathrm{~m}$ & C: 3 Xyl3 & \\
\hline \multirow[t]{2}{*}{5} & $66.5 \mathrm{CH}_{2}$ & 4.14 brd (11.2) & C: 3 Xyl3 & \\
\hline & & $3.59 \mathrm{t}(11.2)$ & C: $1,3,4$ Xyl3 & H-1 Xyl3 \\
\hline \multicolumn{5}{|c|}{ Glc4 $(1 \rightarrow 4$ Xyl1 $)$} \\
\hline 1 & $102.3 \mathrm{CH}$ & $4.89 \mathrm{~d}(8.1)$ & C: 4 Xyl1 & H-4 Xyl1; H-3, 5 Glc4 \\
\hline 2 & $74.0 \mathrm{CH}$ & $3.82 \mathrm{t}(9.1)$ & C: 1 Glc4 & \\
\hline 3 & $86.0 \mathrm{CH}$ & $4.16 \mathrm{t}(9.1)$ & C: 1 MeGlc5 & H-1 MeGlc5; H-1 Glc4 \\
\hline 4 & $69.0 \mathrm{CH}$ & 3.86 t (9.1) & C: 3 Glc4 & \\
\hline 5 & $75.2 \mathrm{CH}$ & $4.03 \mathrm{~m}$ & & H-1 Glc4 \\
\hline 6 & $67.2 \mathrm{CH}_{2}$ & $4.96 \mathrm{~d}(12.2)$ & & \\
\hline & & $4.69 \mathrm{~m}$ & & \\
\hline \multicolumn{5}{|c|}{ MeGlc5 (1 $\rightarrow 3$ Glc4) } \\
\hline 1 & $104.3 \mathrm{CH}$ & $5.18 \mathrm{~d}(8.1)$ & C: 3 Glc 4 & $\begin{array}{c}\text { H-3 Glc4; H-3, } 5 \\
\text { MeGlc5 }\end{array}$ \\
\hline 2 & $74.1 \mathrm{CH}$ & $3.86 \mathrm{t}(9.1)$ & C: 1 MeGlc5 & H-4 MeGlc5 \\
\hline 3 & $85.2 \mathrm{CH}$ & $3.71 \mathrm{t}(9.1)$ & C: 4 MeGlc5; OMe & H-1 MeGlc5 \\
\hline 4 & $76.2 \mathrm{CH}$ & $4.88 \mathrm{t}(9.1)$ & C: 3, 5 MeGlc5 & H-6 MeGlc5 \\
\hline 5 & $76.4 \mathrm{CH}$ & 3.84 t (9.1) & & \\
\hline \multirow[t]{2}{*}{6} & $61.7 \mathrm{CH}_{2}$ & $4.50 \mathrm{~d}(12.2)$ & & \\
\hline & & $4.33 \mathrm{dd}(6.2 ; 12.2)$ & & \\
\hline $\mathrm{OMe}$ & $60.7 \mathrm{CH}_{3}$ & $3.93 \mathrm{~s}$ & C: 3 MeGlc5 & \\
\hline
\end{tabular}

${ }^{a}$ Recorded at $125.67 \mathrm{MHz}$ in $\mathrm{C}_{5} \mathrm{D}_{5} \mathrm{~N} / \mathrm{D}_{2} \mathrm{O}(4 / 1) .{ }^{b}$ Bold $=$ interglycosidic positions. ${ }^{c}$ Italic $=$ sulfate position. ${ }^{d}$ Recorded at $500.12 \mathrm{MHz}$ in $\mathrm{C}_{5} \mathrm{D}_{5} \mathrm{~N} / \mathrm{D}_{2} \mathrm{O}(4 / 1)$. Multiplicity by ${ }^{1} \mathrm{H}$, and 1D TOCSY. The original spectra of $\mathbf{1}$ are provided in Figures S25-S32.

The comparison of the ${ }^{13} \mathrm{C}$ NMR spectra of the carbohydrate parts of 4 and 2 displayed their difference only in the presence of the signals of additional xylose residue (in the bottom semi-chain of 4), as well as the glycosylation effect at C-4 Qui2, whose signal was observed at $\delta_{C} 85.6$, instead of $\delta_{C} 76.2$ (C-4 Qui2), observed in 2. Therefore, the chitonoidosides $F(2)$ and $\mathrm{H}(4)$ can be considered as sequential steps in the biosynthesis of the glycosides in P. chitonoides.

The (-)ESI-MS/MS of 4 (Figure S33) demonstrated the fragmentation of $\left[\mathrm{M}_{2 \mathrm{Na}}-\mathrm{Na}\right]^{-}$ ion at $m / z 1397.5$ resulted in the fragmentary ion-peaks at $m / z 1277.5\left[\mathrm{M}_{2 \mathrm{Na}}-\mathrm{Na}-\mathrm{NaHSO}_{4}\right]^{-}$, $1119.5\left[\mathrm{M}_{2 \mathrm{Na}}-\mathrm{Na}-\mathrm{MeGlcOSO}_{3} \mathrm{Na}+\mathrm{H}\right]^{-}, 1119.5\left[\mathrm{M}_{2 \mathrm{Na}}-\mathrm{Na}-\mathrm{Xyl}-\mathrm{Qui}\right]^{-}, 987.4\left[_{2 \mathrm{Na}}-\mathrm{Na}-\right.$ $\left.\mathrm{MeGlcOSO}_{3} \mathrm{Na}-\mathrm{Xyl}+\mathrm{H}\right]^{-}, 841.4\left[\mathrm{M}_{2 \mathrm{Na}}-\mathrm{Na}-\mathrm{MeGlcOSO}_{3} \mathrm{Na}-\mathrm{Xyl}-\mathrm{Qui}+\mathrm{H}\right]^{-}, 519.0\left[\mathrm{M}_{2 \mathrm{Na}^{-}}\right.$ $\left.\mathrm{Na}-\mathrm{Agl}-\mathrm{MeGlcOSO}_{3} \mathrm{Na}-\mathrm{Xyl}+\mathrm{H}\right]^{-}, 399.0\left[\mathrm{M}_{2 \mathrm{Na}}-\mathrm{Na}-\mathrm{Agl}-\mathrm{MeGlcOSO}_{3} \mathrm{Na}-\mathrm{Xyl}-\mathrm{NaHSO}_{4}\right]^{-}$, 373.0 $\left[\mathrm{M}_{2 \mathrm{Na}}-\mathrm{Na}-\mathrm{Agl}-\mathrm{Xyl}-\mathrm{Qui}-\mathrm{MeGlcOSO}_{3} \mathrm{Na}+\mathrm{H}\right]^{-}, \quad 255.0 \quad\left[\mathrm{M}_{2 \mathrm{Na}}-\mathrm{Na}-\mathrm{Agl}-\right.$ $\left.\mathrm{MeGlcOSO}_{3} \mathrm{Na}-\mathrm{GlcOSO}_{3} \mathrm{Na}-\mathrm{Xyl}+\mathrm{H}\right]^{-}$, confirming both the sequence of monosaccharides and the aglycone structure of 4 . 
These data indicate that chitonoidoside $\mathrm{H}(4)$ is $3 \beta$-O-\{ $\beta$-D-xylopyranosyl- $(1 \rightarrow 4)-\beta$-Dquinovopyranosyl-( $1 \rightarrow 2$ )-[4-O-sodium sulfate-3-O-methyl- $\beta$-D-glucopyranosyl-( $1 \rightarrow 3)-6$ $O$-sodium sulfate- $\beta$-D-glucopyranosyl-( $1 \rightarrow 4)$ ]- $\beta$-D-xylopyranosyl\}-16-oxo-holosta-9(11), 25(26)-diene.

\subsection{Bioactivity of the Glycosides}

The cytotoxic activity of sea cucumber glycosides against different cell types and cell lines, including HeLa and THP-1, has been extensively studied [1,19]. This has led to deeper understanding of the mechanisms of the anticancer activities of glycosides $[7,8,20]$. Different tumor cell lines exhibit different sensitivities to the cytotoxic effects of sea cucumber glycosides, depending on their chemical structures. This can be of special interest for the development of therapy for certain types of cancer [21].

The cytotoxic activities of compounds 1-4 and chitonoidoside E against human erythrocytes and the human cancer cell lines, adenocarcinoma HeLa, colorectal adenocarcinoma DLD-1, monocytes THP-1, and leukemia promyeloblast HL-60 were investigated (Table 6). The previously tested chitonoidoside A [9] and cisplatin were used as the positive controls.

Table 6. The cytotoxic activities of glycosides 1-4, chitonoidoside E, cisplatin and chitonoidoside A (positive controls) against human erythrocytes, HeLa, DLD-1, THP-1 human cell lines.

\begin{tabular}{cccccc}
\hline \multirow{2}{*}{ Glycosides } & \multirow{2}{*}{$\begin{array}{c}\text { ED }_{\mathbf{5 0}}, \boldsymbol{\mu M}, \\
\text { Erythrocytes }\end{array}$} & HeLa & DLD-1 & THP-1 & HL-60 \\
\cline { 3 - 6 } & & $5.73 \pm 0.10$ & $8.93 \pm 1.28$ & $0.58 \pm 0.07$ & $5.73 \pm 0.37$ \\
Chitonoidoside E & $0.45 \pm 0.01$ & $18.00 \pm 0.59$ & $34.12 \pm 2.12$ & $0.58 \pm 0.04$ & $9.97 \pm 0.94$ \\
Chitonoidoside E $_{1}(\mathbf{1})$ & $0.64 \pm 0.01$ & $37.99 \pm 1.36$ & $71.11 \pm 1.22$ & $4.87 \pm 0.47$ & $41.23 \pm 1.11$ \\
Chitonoidoside F (2) $_{\text {Chitonoidoside G (3) }}$ & $1.17 \pm 0.07$ & $14.52 \pm 1.08$ & $12.44 \pm 1.07$ & $4.81 \pm 0.46$ & $8.23 \pm 0.33$ \\
Chitonoidoside H (4) & $0.65 \pm 0.01$ & $17.02 \pm 1.18$ & $36.62 \pm 1.51$ & $2.88 \pm 0.23$ & $8.13 \pm 0.45$ \\
Chitonoidoside A & $1.27 \pm 0.05$ & $39.48 \pm 1.15$ & $32.68 \pm 2.56$ & $2.93 \pm 0.17$ & $8.95 \pm 0.35$ \\
Cisplatin & - & $16.94 \pm 0.25$ & $>80.00$ & $56.12 \pm 3.91$ & $8.58 \pm 0.54$ \\
\hline
\end{tabular}

All the tested compounds demonstrated strong hemolytic activity, with hexaosides 1, 3 and chitonoidoside E proving to be the most active. The human erythrocytes were more sensitive to the membranolytic action of tested compounds (Table 6) compared to the cancer cells, which is similar to previous data concerning mouse erythrocytes $[12,13,15,17]$. The monocyte cell line THP- 1 and the erythrocytes were comparably sensitive to the action of the glycosides.

A similar tendency for 1, 3, and chitonoidoside E was observed for the cytotoxicity against the adenocarcinoma HeLa and HL-60 cells, but the demonstrated effects were moderate. Chitonoidoside E possessing a hexasaccharide chain and the aglycone with a 18(20)-ether bond was the most active; the activity of hexaosides $\mathbf{1}$ and $\mathbf{3}$, which differed through the sixth monosaccharide residue, and the activity of pentaoside 4 , were close to each other against erythrocytes and HeLa and HL-60 cells, but significantly differed in relation to DLD-1 and THP-1 cells. The tetraoside with a shortened bottom semi-chain, chitonoidoside F (2), exhibited the weakest membranolytic effect in the series. The most significant difference in the activity of $\mathbf{2}$ and the other compounds of the series was observed for the DLD-1 and HL-60 cell lines, confirming the diversity in the sensitivities of the cancer cell lines. The presence of the aglycone with an 18(20)-ether bond (in 3) did not decrease the activity of the glycosides. The latter two peculiarities are in good accordance with the biologic activity of a previously analyzed series of chitonoidosides-the glycosides of P. chitonoides [15].

\subsection{Metabolic Network of Carbohydrate Chains of Chitonoidosides of the Groups A-H}

The aglycones and carbohydrate chains of triterpene glycosides are biosynthesized simultaneously and independently from each other $[12,22,23]$, leading to the tremendous 
structural diversity in this class of natural products from sea cucumbers. Glycosides with identical to sugar moieties that differ in their aglycone structures are considered to belong to a group of glycosides named by particular letter (some groups may consist of one compound). Thus, eight groups of chitonoidosides, $\mathrm{A}-\mathrm{H}$, were discovered in P. chitonoides, including three types of tetraosides (groups A, C, and F), differing in their architecture and monosaccharide composition, two types of pentaosides (groups $\mathrm{D}$ and $\mathrm{H}$ ) with analogical differences, and three types of hexaosides (groups B, E, and G), differing in their terminal monosaccharide residues and the positions of their sulfate groups. The biosynthesis of sugar moieties occurs through the sequential connection of monosaccharides to certain positions, forming carbohydrate chains. The first branchpoint in the biosynthesis of the chitonoidosides of diverse groups is the attachment of the third sugar residue to the bioside consisting of Xyl1 and Qui2. When the third sugar (xylose) attaches to C-4 Qui2, with the subsequent attachment of 3-OMeGlc and sulfation, the growth of the sugar chain ends with the formation of tetraosides, namely the chitonoidosides of group A (such chains are considered as linear). The attachment of glucose as the third sugar unit to $\mathrm{C}-4 \mathrm{Xyl1}$, followed by the addition of glycosylation with different monosaccharide residues (3-O-methylxylose or 3-O-methylglucose) and sulfation, leads to the formation of the chitonoidosides of groups $\mathrm{C}$ and $\mathrm{F}$ (Figure 2). The elongation of the bottom semi-chain in chitonoidoside $\mathrm{F}$ (by C-4 Qui2) results in chitonoidoside $\mathrm{H}$ formation. The further elongation of the sugar chains of the chitonoidosides belonging to the group A and additional sulfation lead to the formation of chitonoidosides of the group $\mathrm{D}$, followed by the subsequent formation of chitonoidosides belonging to group $\mathrm{G}$. When the elongation of the sugar chains of the chitonoidosides of group A occurs without sulfation, the chitonoidosides of the group B are biosynthesized.

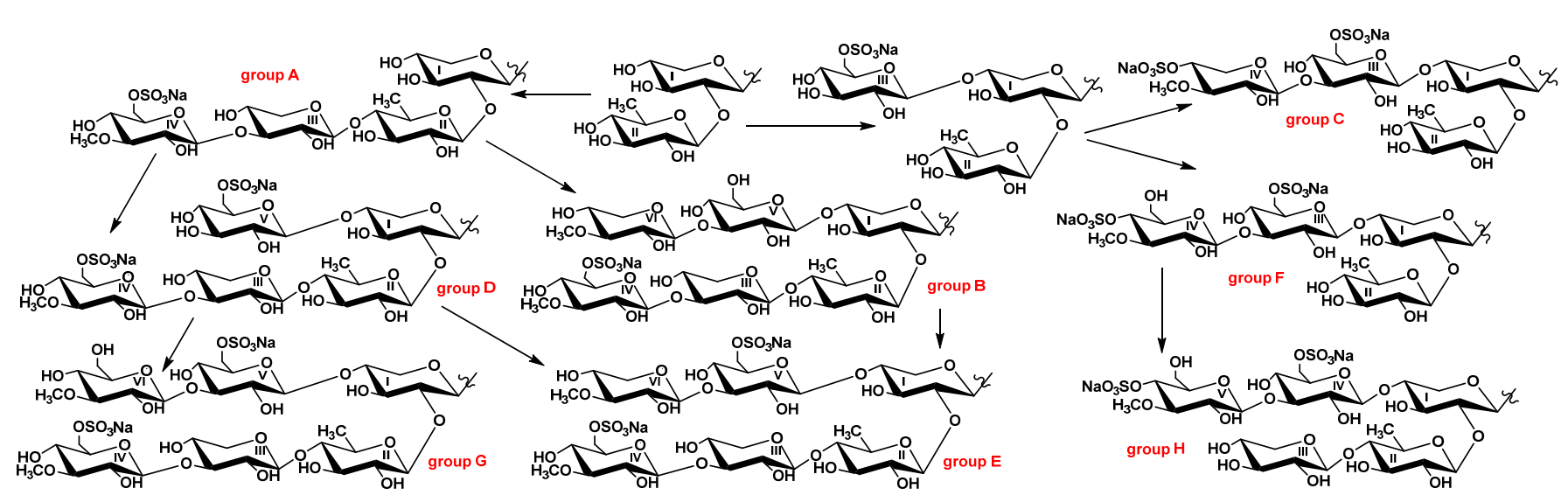

Figure 2. Biosynthetic network of carbohydrate chains of chitonoidosides of the groups A-H.

Noticeably, that the sulfation of terminal monosaccharide in the upper semi-chain of tetraosides-the chitonoidosides of groups $\mathrm{C}$ and $\mathrm{F}$ - precedes the subsequent elongation of the bottom semi-chain. Therefore, these glycosides cannot be the precursors of the chitonoidosides of group E containing non-sulfated terminal 3-O-methylxylose in the upper semi-chain. Similarly, hexaosides-chitonoidosides of group B-with the only sulfate group at C-6 MeGlc4 cannot be formed from pentaosides, the chitonoidosides of group D because, of the sulfation of Glc5 in the latter. Additionally, the carbohydrate chain of the chitonoidosides of group $\mathrm{E}$ can be formed through the sulfation of the chain of chitonoidosides of group B or through the glycosylation of the chain of chitonoidosides of group D. All these data demonstrate that glycosylation and sulfation are competitive and parallel/simultaneous processes in carbohydrate chain biosynthesis. 


\section{Materials and Methods}

\subsection{General Experimental Procedures}

Specific rotation, PerkinElmer 343 Polarimeter (PerkinElmer, Waltham, MA, USA); NMR, Bruker AMX 500 (Bruker BioSpin GmbH, Rheinstetten, Germany) (500.12/125.67 MHz $\left({ }^{1} \mathrm{H} /{ }^{13} \mathrm{C}\right)$ spectrometer; ESI MS (positive and negative ion modes), Agilent $6510 \mathrm{Q}-\mathrm{TOF}$ apparatus (Agilent Technology, Santa Clara, CA, USA), sample concentration $0.01 \mathrm{mg} / \mathrm{mL}$; HPLC, Agilent 1260 Infinity II with a differential refractometer (Agilent Technology, Santa Clara, CA, USA); columns Supelcosil LC-Si $(4.6 \times 150 \mathrm{~mm}, 5 \mu \mathrm{m})$ and Ascentis RP-Amide $(10 \times 250 \mathrm{~mm}, 5 \mu \mathrm{m})$ (Supelco, Bellefonte, PA, USA).

\subsection{Animals and Cells}

The specimens of the holothurian Psolus chitonoides (family Psolidae; order Dendrochirotida) were harvested in the Bering Sea during the 14th expedition cruise on board the r/v "Akademik Oparin" on August 24, 1991, north of Bering Island (Commander Islands). The harvesting was carried out by the Sigsbee trawl at depths of 100-150 m. The animals were taxonomically determined by Dr. Alexey V. Smirnov, Zoological Institute of the Russian Academy of Sciences. Voucher specimens are kept at the Zoological Institute of RAS, St. Petersburg, Russia.

The human erythrocytes were purchased from the Station of Blood Transfusion in Vladivostok. The human adenocarcinoma cell line HeLa cells were provided by the N.N. Blokhin National Medicinal Research Center of Oncology of the Ministry of Health Care of the Russian Federation, (Moscow, Russia). The human colorectal adenocarcinoma cell line DLD-1 CCL-221 ${ }^{\mathrm{TM}}$ cells and the human monocytes THP-1 TIB-202TM, as well as the human promyeloblast cell line HL-60 CCL-240, were received from ATCC (Manassas, VA, USA). The HeLa cell line was cultured in the medium of DMEM (Gibco Dulbecco's Modified Eagle Medium), with a 1\% penicillin/streptomycin sulfate (Biolot, St. Petersburg, Russia) and 10\% fetal bovine serum (FBS) (Biolot, St. Petersburg, Russia). The cells from the DLD-1, HL-60, and THP-1 lines were cultured in an RPMI medium composed of $1 \%$ penicillin/streptomycin (Biolot, St. Petersburg, Russia) and 10\% fetal bovine serum (FBS) (Biolot, St. Petersburg, Russia). All the cells were incubated at $37{ }^{\circ} \mathrm{C}$ in a humidified atmosphere at $5 \%(v / v) \mathrm{CO}_{2}$.

The study was conducted according to the guidelines of the Declaration of Helsinki, and approved by the Ethics Committee of the Pacific Institute of Bioorganic Chemistry (Protocol No. 0037.12.03.2021).

\subsection{Extraction and Isolation}

The sea cucumbers were minced and kept in $\mathrm{EtOH}$ at $+10^{\circ} \mathrm{C}$. Next, they were extracted twice with refluxing $60 \% \mathrm{EtOH}$. The combined extracts were concentrated to dryness in a vacuum, dissolved in $\mathrm{H} 2 \mathrm{O}$, and chromatographed on a Polychrom-1 column (powdered Teflon, Biolar, Latvia). Eluting first the inorganic salts and impurities with $\mathrm{H} 2 \mathrm{O}$ and then the glycosides with $50 \% \mathrm{EtOH}$ produced $3200 \mathrm{mg}$ of crude glycoside fraction, which was submitted to stepwise column chromatography on $\mathrm{Si}$ gel using $\mathrm{CHCl} 3 / \mathrm{EtOH} / \mathrm{H} 2 \mathrm{O}$ (100:75:10), (100:100:17) and (100:125:25) as mobile phases to produce fractions I-IV. The HPLC of fraction III on the silica-based column Supelcosil LC-Si $(4.6 \times 150 \mathrm{~mm}, 5 \mu \mathrm{m})$ with $\mathrm{CHCl}_{3} / \mathrm{MeOH} / \mathrm{H}_{2} \mathrm{O}(60 / 25 / 4)$ as the mobile phase resulted in the isolation of six subfractions (III.1-III.6). The subsequent HPLC of subfraction III.4 on Supelco Ascentis RP-Amide $(10 \times 250 \mathrm{~mm})$ with $\mathrm{CH}_{3} \mathrm{CN} / \mathrm{H}_{2} \mathrm{O} / \mathrm{NH}_{4} \mathrm{OAc}(1 \mathrm{M}$ water solution) $(40 / 59 / 1)$ as the mobile phase resulted in the isolation of seven fractions (III.4.1-III.4.7). Repeated chromatography of III.4.3 on the same column but with $\mathrm{MeOH} / \mathrm{H}_{2} \mathrm{O} / \mathrm{NH}_{4} \mathrm{OAc}(1 \mathrm{M}$ water solution) $(67 / 31 / 2)$ as the mobile phase produced $9.2 \mathrm{mg}$ of chitonoidoside $\mathrm{E}_{1}(\mathbf{1})$. Rechromatography of III.4.6 using mobile phase $\mathrm{MeOH} / \mathrm{H}_{2} \mathrm{O} / \mathrm{NH}_{4} \mathrm{OAc}(1 \mathrm{M}$ water solution) $(68 / 30 / 2)$ produced $4.3 \mathrm{mg}$ of chitonoidoside F (2). Fraction IV obtained after Si gel column chromatography was submitted to HPLC on Supelcosil LC-Si $(4.6 \times 150 \mathrm{~mm}, 5 \mu \mathrm{m})$ with $\mathrm{CHCl}_{3} / \mathrm{MeOH} / \mathrm{H}_{2} \mathrm{O}(63 / 27 / 4)$ as the mobile phase to produce a set of subfractions 
(IV.1-IV.6). Chitonoidoside G (3) (3.7 mg) was isolated as a result of HPLC of subfraction IV.3 on Supelco Ascentis RP-Amide $(10 \times 250 \mathrm{~mm})$ with $\mathrm{MeOH} / \mathrm{H}_{2} \mathrm{O} / \mathrm{NH}_{4} \mathrm{OAc}(1 \mathrm{M}$ water solution) $(72 / 26 / 2)$ as the mobile phase. Chitonoidoside $\mathrm{H}$ (4) (4.7 mg) was obtained after HPLC of subfraction IV.1 on Supelco Ascentis RP-Amide $(10 \times 250 \mathrm{~mm})$ with $\mathrm{MeOH} / \mathrm{H}_{2} \mathrm{O} / \mathrm{NH}_{4} \mathrm{OAc}(1 \mathrm{M}$ water solution) $(70 / 28 / 2)$ as the mobile phase.

\subsubsection{Chitonoidoside $\mathrm{E}_{1}(1)$}

Colorless powder; $(\alpha)_{\mathrm{D}}^{20}-35^{\circ}(c$ 0.1, 50\% MeOH). NMR: See Table S1 and Table 1, Figures S1-S7. (-)HR-ESI-MS m/z: 1543.5315 (calc. 1543.5339) $\left[\mathrm{M}_{2 \mathrm{Na}}-\mathrm{Na}\right]^{-}, 760.2734$ (calc. $^{-}$ 760.2723) $\left[\mathrm{M}_{2 \mathrm{Na}}-2 \mathrm{Na}\right]^{2-}$. (-)ESI-MS/MS m/z: $1423.6\left[\mathrm{M}_{2 \mathrm{Na}}-\mathrm{Na}-\mathrm{NaHSO}_{4}\right]^{-}, 1266.5\left[\mathrm{M}_{2 \mathrm{Na}}-\right.$ $\left.\mathrm{Na}-\mathrm{C}_{7} \mathrm{H}_{12} \mathrm{O}_{8} \mathrm{SNa}\left(\mathrm{MeGlcOSO}{ }_{3} \mathrm{Na}\right)+\mathrm{H}\right]^{-}, 1133.5\left[\mathrm{M}_{2 \mathrm{Na}}-\mathrm{Na}-\mathrm{C}_{7} \mathrm{H}_{12} \mathrm{O}_{8} \mathrm{SNa}\left(\mathrm{MeGlcOSO} \mathrm{Na}_{3}-\right.\right.$ $\left.\mathrm{C}_{5} \mathrm{H}_{8} \mathrm{O}_{4}(\mathrm{Xyl})+\mathrm{H}\right]^{-}, 987.4\left[\mathrm{M}_{2 \mathrm{Na}}-\mathrm{Na}-\mathrm{C}_{7} \mathrm{H}_{12} \mathrm{O}_{8} \mathrm{SNa}\left(\mathrm{MeGlcOSO}{ }_{3} \mathrm{Na}\right)-\mathrm{C}_{5} \mathrm{H}_{8} \mathrm{O}_{4}(\mathrm{Xyl})-\right.$ $\mathrm{C}_{6} \mathrm{H}_{10} \mathrm{O}_{4}$ (Qui) $\left.+\mathrm{H}\right]^{-}, 841.4\left[\mathrm{M}_{2 \mathrm{Na}}-\mathrm{Na}-\mathrm{C}_{7} \mathrm{H}_{12} \mathrm{O}_{8} \mathrm{SNa}\left(\mathrm{MeGlcOSO} \mathrm{O}_{3} \mathrm{Na}\right)-\mathrm{C}_{5} \mathrm{H}_{8} \mathrm{O}_{4}(\mathrm{Xyl})-\right.$ $\mathrm{C}_{6} \mathrm{H}_{10} \mathrm{O}_{4}$ (Qui) $\left.-\mathrm{C}_{6} \mathrm{H}_{11} \mathrm{O}_{4}(\mathrm{MeXyl})+2 \mathrm{H}\right]^{-}$, $665.1\left[\mathrm{M}_{2 \mathrm{Na}}-\mathrm{Na}-\mathrm{C}_{30} \mathrm{H}_{44} \mathrm{O}_{4}(\mathrm{Agl})-\mathrm{C}_{6} \mathrm{H}_{11} \mathrm{O}_{4}\right.$ $\left.(\mathrm{MeXyl})-\mathrm{C}_{6} \mathrm{H}_{9} \mathrm{O}_{8} \mathrm{SNa}\left(\mathrm{GlCOSO}_{3} \mathrm{Na}\right)+\mathrm{H}\right]^{-}, 533.1\left[\mathrm{M}_{2 \mathrm{Na}}-\mathrm{Na}-\mathrm{C}_{30} \mathrm{H}_{44} \mathrm{O}_{4}(\mathrm{Agl})-\mathrm{C}_{6} \mathrm{H}_{11} \mathrm{O}_{4}\right.$ $\left.(\mathrm{MeXyl})-\mathrm{C}_{6} \mathrm{H}_{9} \mathrm{O}_{8} \mathrm{SNa}\left(\mathrm{GlOOSO}_{3} \mathrm{Na}\right)-\mathrm{C}_{5} \mathrm{H}_{8} \mathrm{O}_{4}(\mathrm{Xyl})+\mathrm{H}\right]^{-}, 387.0\left[\mathrm{M}_{2 \mathrm{Na}}-\mathrm{Na}-\mathrm{C}_{30} \mathrm{H}_{44} \mathrm{O}_{4}(\mathrm{Agl})-\right.$ $\left.\mathrm{C}_{6} \mathrm{H}_{11} \mathrm{O}_{4}(\mathrm{MeXyl})-\mathrm{C}_{6} \mathrm{H}_{9} \mathrm{O}_{8} \mathrm{SNa}\left(\mathrm{GlOSO}_{3} \mathrm{Na}\right)-\mathrm{C}_{5} \mathrm{H}_{8} \mathrm{O}_{4}(\mathrm{Xyl})-\mathrm{C}_{6} \mathrm{H}_{10} \mathrm{O}_{4}(\mathrm{Qui})+\mathrm{H}\right]^{-}, 255.0\left[\mathrm{M}_{2 \mathrm{Na}^{-}}\right.$ $\mathrm{Na}-\mathrm{C}_{30} \mathrm{H}_{44} \mathrm{O}_{4}(\mathrm{Agl})-\mathrm{C}_{6} \mathrm{H}_{11} \mathrm{O}_{4}(\mathrm{MeXyl})-\mathrm{C}_{6} \mathrm{H}_{9} \mathrm{O}_{8} \mathrm{SNa}\left(\mathrm{GlOOSO}_{3} \mathrm{Na}\right)-\mathrm{C}_{5} \mathrm{H}_{8} \mathrm{O}_{4}(\mathrm{Xyl})-\mathrm{C}_{6} \mathrm{H}_{10} \mathrm{O}_{4}$ (Qui) $\left.-\mathrm{C}_{5} \mathrm{H}_{8} \mathrm{O}_{4}(\mathrm{Xyl})+\mathrm{H}\right]^{-}$(Figure $\mathrm{S} 8$ ).

\subsubsection{Chitonoidoside F (2)}

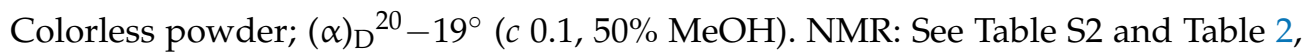
Figures S9-S15. (-)HR-ESI-MS m/z: 1265.4337 (calc. 1265.4337) $\left[\mathrm{M}_{2 \mathrm{Na}}-\mathrm{Na}\right)^{-}, 621.2244$ (calc. 621.2269) $\left(\mathrm{M}_{2 \mathrm{Na}}-2 \mathrm{Na}\right]^{2-}$; (-)ESI-MS/MS m/z: $1146.5\left[\mathrm{M}_{2 \mathrm{Na}}-\mathrm{Na}-\mathrm{NaSO}_{4}\right]^{-}, 987.4\left[\mathrm{M}_{2 \mathrm{Na}}{ }^{-}\right.$ $\left.\mathrm{Na}-\mathrm{C}_{7} \mathrm{H}_{12} \mathrm{O}_{8} \mathrm{SNa}\left(\mathrm{MeGlcOSO}{ }_{3} \mathrm{Na}\right)+\mathrm{H}\right]^{-}, 841.4,\left[\mathrm{M}_{2 \mathrm{Na}}-\mathrm{Na}-\mathrm{C}_{7} \mathrm{H}_{12} \mathrm{O}_{8} \mathrm{SNa}\left(\mathrm{MeGlcOSO} \mathrm{Na}_{3}-\right.\right.$ $\mathrm{C}_{6} \mathrm{H}_{10} \mathrm{O}_{4}$ (Qui)+H] $]^{-}$(Figure S16).

\subsubsection{Chitonoidoside G (3)}

Colorless powder; $(\alpha)_{\mathrm{D}}{ }^{20}-48^{\circ}(c$ 0.1, 50\% MeOH). NMR: See Tables 3 and 4, Figures S17-S23. (-)HR-ESI-MS m/z: 1559.5646 (calc. 1559.5652) $\left[\mathrm{M}_{2 \mathrm{Na}}-\mathrm{Na}\right]^{-}, 768.2895$ (calc. 768.2880) $\left[\mathrm{M}_{2 \mathrm{Na}}-2 \mathrm{Na}\right]^{2-}$; (-)ESI-MS/MS m/z: $1439.6\left[\mathrm{M}_{2 \mathrm{Na}}-\mathrm{Na}-\mathrm{NaHSO}_{4}\right]^{-}, 1383.6$ $\left[\mathrm{M}_{2 \mathrm{Na}}-\mathrm{Na}-\mathrm{C}_{7} \mathrm{H}_{13} \mathrm{O}_{5}(\mathrm{MeGlc})+\mathrm{H}\right]^{-}, 1281.6\left[\mathrm{M}_{2 \mathrm{Na}}-\mathrm{Na}-\mathrm{C}_{7} \mathrm{H}_{12} \mathrm{O}_{8} \mathrm{SNa}\left(\mathrm{MeGlcOSO} \mathrm{Na}_{3}+\mathrm{H}\right]^{-}\right.$, $1149.5\left[\mathrm{M}_{2 \mathrm{Na}}-\mathrm{Na}-\mathrm{C}_{7} \mathrm{H}_{12} \mathrm{O}_{8} \mathrm{SNa}\left(\mathrm{MeGlcOSO} \mathrm{Na}_{3}-\mathrm{C}_{5} \mathrm{H}_{8} \mathrm{O}_{4}(\mathrm{Xyl})+\mathrm{H}\right]^{-}, 1003.5\left[\mathrm{M}_{2 \mathrm{Na}}-\mathrm{Na}-\right.\right.$ $\left.\mathrm{C}_{7} \mathrm{H}_{12} \mathrm{O}_{8} \mathrm{SNa}\left(\mathrm{MeGlcOSO}{ }_{3} \mathrm{Na}\right)-\mathrm{C}_{5} \mathrm{H}_{8} \mathrm{O}_{4}(\mathrm{Xyl})-\mathrm{C}_{6} \mathrm{H}_{10} \mathrm{O}_{4}(\mathrm{Qui})+\mathrm{H}\right]^{-}, 533.1\left[\mathrm{M}_{2 \mathrm{Na}}-\mathrm{Na}-\right.$ $\mathrm{C}_{30} \mathrm{H}_{46} \mathrm{O}_{3}(\mathrm{Agl})-\mathrm{C}_{7} \mathrm{H}_{13} \mathrm{O}_{5}(\mathrm{MeGlc})-\mathrm{C}_{7} \mathrm{H}_{12} \mathrm{O}_{8} \mathrm{SNa}\left(\mathrm{MeGlcOSO} \mathrm{Na}_{3}-\mathrm{C}_{5} \mathrm{H}_{8} \mathrm{O}_{4}(\mathrm{Xyl})+\mathrm{H}\right]^{-}$, $387.0\left[\mathrm{M}_{2 \mathrm{Na}}-\mathrm{Na}-\mathrm{C}_{30} \mathrm{H}_{46} \mathrm{O}_{3}(\mathrm{Agl})-\mathrm{C}_{7} \mathrm{H}_{13} \mathrm{O}_{5}\right.$ (MeGlc) $-\mathrm{C}_{7} \mathrm{H}_{12} \mathrm{O}_{8} \mathrm{SNa}\left(\mathrm{MeGlcOSO} \mathrm{Na}_{3}\right)$ $\mathrm{C}_{5} \mathrm{H}_{8} \mathrm{O}_{4}(\mathrm{Xyl})-\mathrm{C}_{6} \mathrm{H}_{10} \mathrm{O}_{4}$ (Qui)+H] $]^{-}, 255.0\left[\mathrm{M}_{2 \mathrm{Na}}-\mathrm{Na}-\mathrm{C}_{30} \mathrm{H}_{46} \mathrm{O}_{3}\right.$ (Agl) $-\mathrm{C}_{7} \mathrm{H}_{13} \mathrm{O}_{5}$ (MeGlc)$\mathrm{C}_{7} \mathrm{H}_{12} \mathrm{O}_{8} \mathrm{SNa} \quad\left(\mathrm{MeGlcOSO} \mathrm{Na}_{3}-\mathrm{C}_{5} \mathrm{H}_{8} \mathrm{O}_{4} \quad(\mathrm{Xyl})-\mathrm{C}_{6} \mathrm{H}_{10} \mathrm{O}_{4} \quad \text { (Qui) }-\mathrm{C}_{5} \mathrm{H}_{8} \mathrm{O}_{4} \quad(\mathrm{Xyl})+\mathrm{H}\right]^{-}$ (Figure S24).

\subsubsection{Chitonoidoside $\mathrm{H}(4)$}

Colorless powder; $(\alpha)_{\mathrm{D}}{ }^{20}-28^{\circ}(c$ 0.1, 50\% MeOH). NMR: See Tables S3 and 5, Figures S25-S32. (-)HR-ESI-MS m/z: 1397.4749 (calc. 1397.4760) $\left[\mathrm{M}_{2 \mathrm{Na}}-\mathrm{Na}\right]^{-}, 687.2442$ (calc. 687.2434) $\left[\mathrm{M}_{2 \mathrm{Na}}-2 \mathrm{Na}\right]^{2-}$; (-)ESI-MS/MS m/z: $1277.5\left[\mathrm{M}_{2 \mathrm{Na}}-\mathrm{Na}-\mathrm{NaHSO}_{4}\right]^{-}, 1119.5$ $\left[\mathrm{M}_{2 \mathrm{Na}}-\mathrm{Na}-\mathrm{C}_{7} \mathrm{H}_{12} \mathrm{O}_{8} \mathrm{SNa}(\mathrm{MeGlcOSO} 3 \mathrm{Na})+\mathrm{H}\right]^{-}, 1119.5\left[\mathrm{M}_{2 \mathrm{Na}}-\mathrm{Na}-\mathrm{C}_{5} \mathrm{H}_{8} \mathrm{O}_{4}(\mathrm{Xyl})-\mathrm{C}_{6} \mathrm{H}_{10} \mathrm{O}_{4}\right.$ (Qui) $]^{-}, 987.4\left[\mathrm{M}_{2 \mathrm{Na}}-\mathrm{Na}-\mathrm{C}_{7} \mathrm{H}_{12} \mathrm{O}_{8} \mathrm{SNa}\left(\mathrm{MeGlcOSO}{ }_{3} \mathrm{Na}\right)-\mathrm{C}_{5} \mathrm{H}_{8} \mathrm{O}_{4}(\mathrm{Xyl})+\mathrm{H}\right]^{-}, 841.4\left[\mathrm{M}_{2 \mathrm{Na}}{ }^{-}\right.$ $\mathrm{Na}-\mathrm{C}_{7} \mathrm{H}_{12} \mathrm{O}_{8} \mathrm{SNa}\left(\mathrm{MeGlcOSO}{ }_{3} \mathrm{Na}\right)-\mathrm{C}_{5} \mathrm{H}_{8} \mathrm{O}_{4}(\mathrm{Xyl})-\mathrm{C}_{6} \mathrm{H}_{10} \mathrm{O}_{4}$ (Qui) $\left.+\mathrm{H}\right]^{-}, 519.0\left[\mathrm{M}_{2 \mathrm{Na}}-\right.$ $\left.\mathrm{Na}-\mathrm{C}_{30} \mathrm{H}_{44} \mathrm{O}_{4}(\mathrm{Agl})-\mathrm{C}_{7} \mathrm{H}_{12} \mathrm{O}_{8} \mathrm{SNa}\left(\mathrm{MeGlcOSO}{ }_{3} \mathrm{Na}\right)-\mathrm{C}_{5} \mathrm{H}_{8} \mathrm{O}_{4}(\mathrm{Xyl})+\mathrm{H}\right]^{-}, 399.0\left[\mathrm{M}_{2 \mathrm{Na}}-\mathrm{Na}-\right.$ $\mathrm{C}_{30} \mathrm{H}_{44} \mathrm{O}_{4}(\mathrm{Agl})-\mathrm{C}_{7} \mathrm{H}_{12} \mathrm{O}_{8} \mathrm{SNa}\left(\mathrm{MeGlcOSO} \mathrm{Na}_{3}-\mathrm{C}_{5} \mathrm{H}_{8} \mathrm{O}_{4}(\mathrm{Xyl})-\mathrm{NaHSO}_{4}\right]^{-}, 373.0\left[\mathrm{M}_{2 \mathrm{Na}}-\right.$ $\left.\mathrm{Na}-\mathrm{C}_{30} \mathrm{H}_{44} \mathrm{O}_{4}(\mathrm{Agl})-\mathrm{C}_{5} \mathrm{H}_{8} \mathrm{O}_{4}(\mathrm{Xyl})-\mathrm{C}_{6} \mathrm{H}_{10} \mathrm{O}_{4}(\mathrm{Qui})-\mathrm{C}_{7} \mathrm{H}_{12} \mathrm{O}_{8} \mathrm{SNa}\left(\mathrm{MeGlcOSO}{ }_{3} \mathrm{Na}\right)+\mathrm{H}\right]^{-}$, $255.0\left[\mathrm{M}_{2 \mathrm{Na}}-\mathrm{Na}-\mathrm{C}_{30} \mathrm{H}_{46} \mathrm{O}_{3}(\mathrm{Agl})-\mathrm{C}_{7} \mathrm{H}_{12} \mathrm{O}_{8} \mathrm{SNa}\left(\mathrm{MeGlcOSO} \mathrm{Na}_{3}-\mathrm{C}_{6} \mathrm{H}_{9} \mathrm{O}_{8} \mathrm{SNa}\left(\mathrm{GlOSO}_{3} \mathrm{Na}\right)-\right.\right.$ $\left.\mathrm{C}_{5} \mathrm{H}_{8} \mathrm{O}_{4}(\mathrm{Xyl})+\mathrm{H}\right]^{-}$(Figure S33). 


\subsection{Cytotoxic Activity (MTT Assay Applied for HeLa Cells)}

All the studied substances (including the chitonoidoside A and cisplatin, used as positive controls) were tested in concentrations from $0.1 \mu \mathrm{M}$ to $100 \mu \mathrm{M}$ using twofold dilution in $\mathrm{d}-\mathrm{H} 2 \mathrm{O}$. The cell suspension $(180 \mu \mathrm{L})$ and solutions $(20 \mu \mathrm{L})$ of the tested compounds in different concentrations were injected in wells of 96 well plates $(1 \times 104$ cells/well $)$ and incubated at $37^{\circ} \mathrm{C}$ for $24 \mathrm{~h}$ in $5 \% \mathrm{CO}_{2}$. After incubation, the tested substances with medium were replaced by $100 \mu \mathrm{L}$ of fresh medium. Next, $10 \mu \mathrm{L}$ of MTT (3-(4,5-dimethylthiazol-2yl)-2,5-diphenyltetrazolium bromide) (Sigma-Aldrich, St. Louis, MO, USA) stock solution $(5 \mathrm{mg} / \mathrm{mL}$ ) was added to each well, followed by the incubation of the microplate for $4 \mathrm{~h}$. Subsequently, $100 \mu \mathrm{L}$ of SDS- $\mathrm{HCl}$ solution $(1 \mathrm{~g} \mathrm{SDS} / 10 \mathrm{~mL} \mathrm{~d}-\mathrm{H} 2 \mathrm{O} / 17 \mu \mathrm{L} 6 \mathrm{~N} \mathrm{HCl})$ was added to each well and incubated for $18 \mathrm{~h}$. The absorbance of the converted dye, formazan, was measured with a Multiskan FC microplate photometer (Thermo Fisher Scientific, Waltham, MA, USA) at $570 \mathrm{~nm}$. The cytotoxic activity of the tested compounds was calculated as the concentration that caused $50 \%$ cell metabolic activity inhibition (IC50). The experiments were carried out in triplicate, $p<0.05$.

\subsection{Cytotoxic Activity (MTS Assay Applied for DLD-1, THP-1 and HL-60 Cells)}

The cells of the HL-60 line $\left(6 \times 10^{3} / 200 \mu \mathrm{L}\right)$ were placed in 96 well plates at $37^{\circ} \mathrm{C}$ for $24 \mathrm{~h}$ in a $5 \% \mathrm{CO}_{2}$ incubator. The cells were treated with tested substances and chitonoidoside $\mathrm{A}$ and cisplatin were used as positive controls at concentrations from 0 to $100 \mu \mathrm{M}$ for an additional $24 \mathrm{~h}$ of incubation. Next, the cells were incubated with $10 \mu \mathrm{L}$ MTS (3-(4,5dimethylthiazol-2-yl)-5-(3-carboxymethoxyphenyl)-2-(4-sulfophenyl)-2H-tetrazolium) for $4 \mathrm{~h}$, and the absorbance in each well was measured at 490/630 $\mathrm{nm}$ with plate reader PHERA star FS (BMG Labtech, Ortenberg, Germany). The experiments were carried out in triplicate and the mean absorbance values were calculated. The results were presented as the percentage of inhibition that produced a reduction in absorbance after the tested compound treatment compared to the non-treated cells (negative control), $p<0.01$.

\subsection{Hemolytic Activity}

The erythrocytes were isolated from human blood through centrifugation with phosphatebuffered saline (PBS) (pH 7.4) at $4{ }^{\circ} \mathrm{C}$ for 5 min by $450 \times g$ on centrifuge LABOFUGE $400 \mathrm{R}$ (Heraeus, Hanau, Germany) three times. Next, the residue of the erythrocytes was resuspended in an ice-cold phosphate saline buffer ( $\mathrm{pH}$ 7.4) to a final optical density of 1.5 at $700 \mathrm{~nm}$, and kept on ice. For the hemolytic assay, $180 \mu \mathrm{L}$ of erythrocyte suspension was mixed with $20 \mu \mathrm{L}$ of test compound solution (including chitonoidoside A used as positive control) in V-bottom 96 well plates. After $1 \mathrm{~h}$ of incubation at $37^{\circ} \mathrm{C}$, the plates were exposed to centrifugation for $10 \mathrm{~min}$ at $900 \times g$ on laboratory centrifuge LMC-3000 (Biosan, Riga, Latvia). Next, $100 \mu \mathrm{L}$ of supernatant was carefully selected and transferred into new flat-plates, respectively. The lysis of the erythrocytes was determined by measuring of the concentration of hemoglobin in the supernatant with microplate photometer Multiskan FC (Thermo Fisher Scientific, Waltham, MA, USA), $\lambda=570 \mathrm{~nm}$. The effective dose causing $50 \%$ hemolysis of erythrocytes (ED50) was calculated using the computer program SigmaPlot 10.0. All the experiments were performed in triplicate, $p<0.01$.

\section{Conclusions}

The continuation of the research into triterpene glycosides from the sea cucumber Psolus chitonoides resulted in the isolation of four previously unknown chitonoidosides $\mathrm{E}_{1}$ (1), F (2), G (3) and H (4). The compounds characterized by two types of the aglycones (holotoxinogenin and its structural analog with 18(20)-epoxy-cycle instead of a lactone) were also found earlier in the series of chitonoidosides A-E. The compounds 1-4 differed in the number of monosaccharides in their sugar chains (from four to six), the architecture of these chains (for tetra- and pentaosides), their monosaccharide composition, and the positions of their sulfate groups. Terminal 3-O-methylglucose unit was sulfated by $\mathrm{C}-4$ in chitonoidosides $\mathrm{F}(2)$ and $\mathrm{H}(4)$, which is a rare position for a sulfate group 
from sea cucumber glycosides. Notably, in the first series of the studied glycosides from P. chitonoides [15] 3-O-methylxylose residue sulfated by C-4 was found. This indicates the presence of specific sulfatase in this species of the sea cucumber, capable of attaching the sulfate group to C-4 of monosaccharides in pyranose form. The observed "structureactivity relationships" were as follows: tetraosides with a shortened bottom semi-chain displayed the weakest membranolytic effect; and the activity of the glycosides with the new-type aglycone with a 18(20)-ether bond instead of 18(20)-lactone was comparable with that of the substances with holostane-type aglycones. Hexaosides and tetraosides with linear carbohydrate chains (having bottom semi-chain) were the most active in the series of the glycosides from $P$. chitonoides. The pathways of the biosynthetic transformations were analyzed based on the structures of eight types of carbohydrate chains found in the glycosides of $P$. chitonoides. The analysis revealed and confirmed that glycosylation and sulfation are parallel and competitive processes. All the discussed data broaden knowledge about structural diversity of triterpene glycosides from the sea cucumbers and help us to the understand the complicated biosynthesis process of this class of metabolites, which is currently a large gap in knowledge for scientists.

Supplementary Materials: The following are available online at https:/ / www.mdpi.com/article/ $10.3390 / \mathrm{md19120696/s1.} \mathrm{Figure} \mathrm{S1.} \mathrm{The}{ }^{13} \mathrm{C}$ NMR (125.67 MHz) spectrum of chitonoidoside $\mathrm{E}_{1}$ (1) in $\mathrm{C}_{5} \mathrm{D}_{5} \mathrm{~N} / \mathrm{D}_{2} \mathrm{O}(4 / 1)$; Figure S2. The ${ }^{1} \mathrm{H}$ NMR $(500.12 \mathrm{MHz})$ spectrum of chitonoidoside $\mathrm{E}_{1}(\mathbf{1})$ in $\mathrm{C}_{5} \mathrm{D}_{5} \mathrm{~N} / \mathrm{D}_{2} \mathrm{O}(4 / 1)$; Figure $\mathrm{S} 3$. The COSY $(500.12 \mathrm{MHz})$ spectrum of chitonoidoside $\mathrm{E}_{1}$ (1) in $\mathrm{C}_{5} \mathrm{D}_{5} \mathrm{~N} / \mathrm{D}_{2} \mathrm{O}(4 / 1)$; Figure S4. The HSQC $(500.12 \mathrm{MHz})$ spectrum of chitonoidoside $\mathrm{E}_{1}(\mathbf{1})$ in $\mathrm{C}_{5} \mathrm{D}_{5} \mathrm{~N} / \mathrm{D}_{2} \mathrm{O}(4 / 1)$; Figure S5. The ROESY (500.12 MHz) spectrum of chitonoidoside $\mathrm{E}_{1}$ (1) in $\mathrm{C}_{5} \mathrm{D}_{5} \mathrm{~N} / \mathrm{D}_{2} \mathrm{O}(4 / 1)$; Figure S6. The HMBC $(500.12 \mathrm{MHz})$ spectrum of chitonoidoside $\mathrm{E}_{1}(\mathbf{1})$ in $\mathrm{C}_{5} \mathrm{D}_{5} \mathrm{~N} / \mathrm{D}_{2} \mathrm{O}(4 / 1)$; Figure S7. 1 D TOCSY (500.12 MHz) spectra of Xyl1, Qui2, Xyl3, MeGlc4, Glc5 and MeXyl6 of chitonoidoside $\mathrm{E}_{1}(\mathbf{1})$ in $\mathrm{C}_{5} \mathrm{D}_{5} \mathrm{~N} / \mathrm{D}_{2} \mathrm{O}(4 / 1)$; Figure S8. HR-ESI-MS and ESI-MS/MS spectra of chitonoidoside $\mathrm{E}_{1}$ (1); Table S1. ${ }^{13} \mathrm{C}$ and ${ }^{1} \mathrm{H}$ NMR chemical shifts, HMBC and ROESY correlations of aglycone moiety of chitonoidoside $\mathrm{E}_{1}$ (1); Figure S9. The ${ }^{13} \mathrm{C}$ NMR $(125.67 \mathrm{MHz})$ spectrum of chitonoidoside F (2) in $\mathrm{C}_{5} \mathrm{D}_{5} \mathrm{~N} / \mathrm{D}_{2} \mathrm{O}(4 / 1)$; Figure S10. The ${ }^{1} \mathrm{H}$ NMR $(500.12 \mathrm{MHz})$ spectrum of chitonoidoside $\mathrm{F}(2)$ in $\mathrm{C}_{5} \mathrm{D}_{5} \mathrm{~N} / \mathrm{D}_{2} \mathrm{O}(4 / 1)$; Figure S11. The COSY (500.12 MHz) spectrum of chitonoidoside $\mathrm{F}(2)$ in $\mathrm{C}_{5} \mathrm{D}_{5} \mathrm{~N} / \mathrm{D}_{2} \mathrm{O}(4 / 1)$; Figure $\mathrm{S} 12$. The HSQC (500.12 MHz) spectrum of chitonoidoside $\mathrm{F}$ (2) in $\mathrm{C}_{5} \mathrm{D}_{5} \mathrm{~N} / \mathrm{D}_{2} \mathrm{O}(4 / 1)$; Figure S13. The HMBC (500.12 MHz) spectrum of chitonoidoside $\mathrm{F}(2)$ in $\mathrm{C}_{5} \mathrm{D}_{5} \mathrm{~N} / \mathrm{D}_{2} \mathrm{O}(4 / 1)$; Figure S14. The ROESY $(500.12 \mathrm{MHz})$ spectrum of chitonoidoside $\mathrm{F}$ (2) in $\mathrm{C}_{5} \mathrm{D}_{5} \mathrm{~N} / \mathrm{D}_{2} \mathrm{O}$ (4/1); Figure S15. 1D TOCSY (500.12 MHz) spectra of Xyl1, Qui2, Glc3 and MeGlc4 of chitonoidoside F (2) in $\mathrm{C}_{5} \mathrm{D}_{5} \mathrm{~N} / \mathrm{D}_{2} \mathrm{O}(4 / 1)$; Figure S16. HR-ESI-MS and ESIMS/MS spectra of chitonoidoside F (2); Table S2. ${ }^{13} \mathrm{C}$ and ${ }^{1} \mathrm{H}$ NMR chemical shifts, $\mathrm{HMBC}$ and ROESY correlations of the aglycone part of chitonoidoside F (2); Figure S17. The ${ }^{13} \mathrm{C}$ NMR (125.67 MHz) spectrum of chitonoidoside $\mathrm{G}(3)$ in $\mathrm{C}_{5} \mathrm{D}_{5} \mathrm{~N} / \mathrm{D}_{2} \mathrm{O}(4 / 1)$; Figure S18. The ${ }^{1} \mathrm{H} N \mathrm{NMR}(500.12 \mathrm{MHz})$ spectrum of chitonoidoside $\mathrm{G}(3)$ in $\mathrm{C}_{5} \mathrm{D}_{5} \mathrm{~N} / \mathrm{D}_{2} \mathrm{O}(4 / 1)$; Figure $\mathrm{S} 19$. The COSY $(500.12 \mathrm{MHz})$ spectrum of chitonoidoside $\mathrm{G}(3)$ in $\mathrm{C}_{5} \mathrm{D}_{5} \mathrm{~N} / \mathrm{D}_{2} \mathrm{O}(4 / 1)$; Figure S20. The HSQC (500.12 MHz) spectrum of chitonoidoside $\mathrm{G}(3)$ in $\mathrm{C}_{5} \mathrm{D}_{5} \mathrm{~N} / \mathrm{D}_{2} \mathrm{O}(4 / 1)$; Figure S21. The HMBC (500.12 MHz) spectrum of chitonoidoside $\mathrm{G}(3)$ in $\mathrm{C}_{5} \mathrm{D}_{5} \mathrm{~N} / \mathrm{D}_{2} \mathrm{O}(4 / 1)$; Figure S22. The ROESY (500.12 MHz) spectrum of chitonoidoside $\mathrm{G}$ (3) in $\mathrm{C}_{5} \mathrm{D}_{5} \mathrm{~N} / \mathrm{D}_{2} \mathrm{O}(4 / 1)$; Figure S23. 1 D TOCSY (500.12 MHz) spectra of Xyl1, Qui2, Xyl3, MeGlc4, Glc5 and MeGlc6 of chitonoidoside G (3) in $\mathrm{C}_{5} \mathrm{D}_{5} \mathrm{~N} / \mathrm{D}_{2} \mathrm{O}(4 / 1)$; Figure S24. HR-ESI-MS and ESI-MS/MS spectra of chitonoidoside G (3); Figure S25. The ${ }^{13} \mathrm{C}$ NMR $(125.67 \mathrm{MHz})$ spectrum of chitonoidoside $\mathrm{H}(4)$ in $\mathrm{C}_{5} \mathrm{D}_{5} \mathrm{~N} / \mathrm{D}_{2} \mathrm{O}(4 / 1)$; Figure S26. The ${ }^{1} \mathrm{H}$ NMR $(500.12 \mathrm{MHz})$ spectrum of chitonoidoside $\mathrm{H}(4)$ in $\mathrm{C}_{5} \mathrm{D}_{5} \mathrm{~N} / \mathrm{D}_{2} \mathrm{O}(4 / 1)$; Figure $\mathrm{S} 27$. The COSY $(500.12 \mathrm{MHz})$ spectrum of chitonoidoside $\mathrm{H}(4)$ in $\mathrm{C}_{5} \mathrm{D}_{5} \mathrm{~N} / \mathrm{D}_{2} \mathrm{O}(4 / 1)$; Figure S28. The HSQC (500.12 MHz) spectrum of chitonoidoside $\mathrm{H}(4)$ in $\mathrm{C}_{5} \mathrm{D}_{5} \mathrm{~N} / \mathrm{D}_{2} \mathrm{O}(4 / 1)$; Figure S29. The ROESY $(500.12 \mathrm{MHz})$ spectrum of chitonoidoside $\mathrm{H}(4)$ in $\mathrm{C}_{5} \mathrm{D}_{5} \mathrm{~N} / \mathrm{D}_{2} \mathrm{O}(4 / 1)$; Figure $\mathrm{S} 30$. The HMBC $(500.12 \mathrm{MHz})$ spectrum of chitonoidoside $\mathrm{H}(4)$ in $\mathrm{C}_{5} \mathrm{D}_{5} \mathrm{~N} / \mathrm{D}_{2} \mathrm{O}(4 / 1)$; Figure S31. 1D TOCSY (500.12 MHz) spectra of Xyl1, Qui2, Xyl3, Glc4 and MeGlc5 of chitonoidoside $\mathrm{H}(4)$ in $\mathrm{C}_{5} \mathrm{D}_{5} \mathrm{~N} / \mathrm{D}_{2} \mathrm{O}(4 / 1)$; Figure S32. 2D TOCSY (500.12 MHz) spectrum of chitonoidoside $\mathrm{H}$ (4) in $\mathrm{C}_{5} \mathrm{D}_{5} \mathrm{~N} / \mathrm{D}_{2} \mathrm{O}(4 / 1)$; Figure S33. HR-ESI-MS and ESI-MS/MS spectra of chitonoidoside $\mathrm{H}(4)$; Table S3. ${ }^{13} \mathrm{C}$ and ${ }^{1} \mathrm{H}$ NMR chemical shifts, HMBC and ROESY correlations of the aglycone part of chitonoidoside $\mathrm{H}(4)$. 
Author Contributions: Conceptualization, A.S.S., V.I.K.; methodology, A.S.S., S.A.A., V.I.K.; investigation, A.S.S., V.I.K., A.I.K., S.A.A., R.S.P., P.S.D., E.A.C., P.V.A.; writing-original draft preparation, A.S.S., V.I.K. writing-review and editing, A.S.S., V.I.K. All authors have read and agreed to the published version of the manuscript.

Funding: The investigation was carried out with the financial support of a grant from the Ministry of Science and Higher Education, Russian Federation, Grant No. 13.1902.21.0012, Contract No. 075-15-2020-796.

Institutional Review Board Statement: The study was conducted according to the guidelines of the Declaration of Helsinki, and approved by the Ethics Committee of the Pacific Institute of Bioorganic Chemistry (Protocol No. 0037.12.03.2021).

Informed Consent Statement: Not applicable.

Acknowledgments: The study was carried out using the equipment of the Collective Facilities Center “The Far Eastern Center for Structural Molecular Research (NMR/MS) PIBOC FEB RAS". The authors are grateful to Valentin Stonik for reading the manuscript and providing useful comments.

Conflicts of Interest: The authors declare no conflict of interest.

\section{References}

1. Aminin, D.L.; Menchinskaya, E.S.; Pislyagin, E.A.; Silchenko, A.S.; Avilov, S.A.; Kalinin, V.I. Sea cucumber triterpene glycosides as anticancer agents. In Studies in Natural Product Chemistry; Rahman, A.U., Ed.; Elsevier B.V.: Amsterdam, The Netherlands, 2016; Volume 49, pp. 55-105.

2. Khotimchenko, Y. Pharmacological potential of sea cucumbers. Int. J. Mol. Sci. 2020, 19, 1342. [CrossRef] [PubMed]

3. Menchinskaya, E.S.; Gorpenchenko, T.Y.; Silchenko, A.S.; Avilov, S.A.; Aminin, D.L. Modulation of doxorubicin intracellular accumulation and anticancer activity by triterpene glycoside cucumarioside A2-2. Mar. Drugs 2019, 17, 597. [CrossRef] [PubMed]

4. Zhao, Y.-C.; Xue, C.-H.; Zhang, T.T.; Wang, Y.-M. Saponins from sea cucumber and their biological activities. Agric. Food Chem. 2018, 66, 7222-7237. [CrossRef] [PubMed]

5. Gomes, A.R.; Freitas, A.C.; Duarte, A.C.; Rocha-Santos, T.A.P. Echinoderms: A review of bioactive compounds with potential health effects. In Studies in Natural Products Chemistry; Rahman, A.U., Ed.; Elsevier B.V.: Amsterdam, The Netherlands, 2016; Volume 49, pp. 1-54.

6. Aminin, D.; Pisliagin, E.; Astashev, M.; Es'kov, A.; Kozhemyako, V.; Avilov, S.; Zelepuga, E.; Yurchenko, E.; Kaluzhskiy, L.; Kozlovskaya, E.; et al. Glycosides from edible sea cucumbers stimulate macrophages via purinergic receptors. Sci. Rep. 2016, 6, 39683. [CrossRef] [PubMed]

7. Dyshlovoy, S.A.; Madanchi, R.; Hauschild, J.; Otte, K.; Alsdorf, W.H.; Schumacher, U.; Kalinin, V.I.; Silchenko, A.S.; Avilov, S.A.; Honecker, F.; et al. The marine triterpene glycoside frondoside A induces p53-independent apoptosis and inhibits autophagy in urothelial carcinoma cells. BMC Cancer 2017, 17, 93. [CrossRef] [PubMed]

8. Yun, S.-H.; Sim, E.-H.; Han, S.-H.; Kim, T.-R.; Ju, M.-H.; Han, J.-Y.; Jeong, J.-S.; Kim, S.-H.; Silchenko, A.S.; Stonik, V.A.; et al. In vitro and in vivo anti-leukemic effects of cladoloside $\mathrm{C} 2$ are mediated by activation of Fas/ceramide syntase 6/P38 kinase/CJun NH2-terminal kinase/caspase-8. Oncotarget 2018, 9, 495-511. [CrossRef] [PubMed]

9. Omran, N.E.; Salem, H.K.; Eissa, S.H.; Kabbash, A.M.; Kandeil, M.A.; Salem, M.A. Chemotaxonomic study of the most abundant Egyptian sea-cucumbers using ultra-performance liquid chromatography (UPLC) coupled to high-resolution mass spectrometry (HRMS). Chemoecology 2020, 30, 35-48. [CrossRef]

10. Kalinin, V.I.; Silchenko, A.S.; Avilov, S.A. Taxonomic significance and ecological role of triterpene glycosides from holothurians. Biol. Bull. 2016, 43, 532-540. [CrossRef]

11. Kalinin, V.I.; Avilov, S.A.; Silchenko, A.S.; Stonik, V.A. Triterpene Glycosides of Sea Cucumbers (Holothuroidea, Echinodermata) as Taxonomic Markers. Nat. Prod. Commun. 2015, 10, 21-26. [CrossRef] [PubMed]

12. Silchenko, A.S.; Kalinovsky, A.I.; Avilov, S.A.; Andrijaschenko, P.V.; Popov, R.S.; Dmitrenok, P.S.; Chingizova, E.A.; Kalinin, V.I. Triterpene Glycosides from the Far Eastern Sea Cucumber Thyonidium (=Duasmodactyla) kurilensis (Levin): The Structures, Cytotoxicities, and Biogenesis of Kurilosides A3, D1, G, H, I, I1, J, K, and K1. Mar. Drugs 2021, 19, 187. [CrossRef] [PubMed]

13. Silchenko, A.S.; Kalinovsky, A.I.; Avilov, S.A.; Kalinin, V.I.; Andrijaschenko, P.V.; Dmitrenok, P.S.; Popov, R.S.; Chingizova, E.A.; Ermakova, S.P.; Malyarenko, O.S. Structures and bioactivities of six new triterpene glycosides, psolusosides E, F, G, H, H $\mathrm{H}_{1}$ and I and the corrected structure of psolusoside B from the sea cucumber Psolus fabricii. Mar. Drugs 2019, 17, 358. [CrossRef]

14. Zelepuga, E.A.; Silchenko, A.S.; Avilov, S.A.; Kalinin, V.I. Structure-activity relationships of holothuroid's triterpene glycosides and some in silico insights obtained by molecular dynamics study on the mechanisms of their membranolytic action. Mar. Drugs 2021, 19, 604. [CrossRef] [PubMed]

15. Silchenko, A.S.; Kalinovsky, A.I.; Avilov, S.A.; Andrijaschenko, P.V.; Popov, R.S.; Dmitrenok, P.S.; Chingizova, E.A.; Kalinin, V.I. Unusual Structures and Cytotoxicities of Chitonoidosides A, A , B, C, D, and E, Six Triterpene Glycosides from the Far Eastern Sea Cucumber Psolus chitonoides. Mar. Drugs 2021, 19, 449. [CrossRef] [PubMed] 
16. Maltsev, I.I.; Stonik, V.A.; Kalinovsky, A.I.; Elyakov, G.B. Triterpene glycosides from sea cucumber Stichopus japonicus Selenka. Comp. Biochem. Physiol. 1984, 78B, 421-426. [CrossRef]

17. Silchenko, A.S.; Kalinovsky, A.I.; Avilov, S.A.; Andrijaschenko, P.V.; Popov, R.S.; Dmitrenok, P.S.; Chingizova, E.A.; Ermakova, S.P.; Malyarenko, O.S.; Dautov, S.S.; et al. Structures and bioactivities of quadrangularisosides A, A $1, B, B_{1}, B_{2}, C, C_{1}, D_{1}, D_{1}-D_{4}$, and $\mathrm{E}$ from the sea cucumber Colochirus quadrangularis: The first discovery of the glycosides, sulfated by $\mathrm{C}-4$ of the terminal 3-O-methylglucose residue. Synergetic effect on colony formation of tumor HT-29 cells of these glycosides with radioactive irradiation. Mar. Drugs 2020, 18, 394.

18. Silchenko, A.S.; Kalinovsky, A.I.; Avilov, S.A.; Andrijaschenko, P.V.; Popov, R.S.; Dmitrenok, P.S.; Chingizova, E.A.; Kalinin, V.I. Kurilosides $\mathrm{A}_{1}, \mathrm{~A}_{2}, \mathrm{C}_{1}, \mathrm{D}, \mathrm{E}$ and F-triterpene glycosides from the Far Eastern sea cucumber Thyonidium (=Duasmodactyla) kurilensis (Levin): Structures with unusual non-holostane aglycones and cytotoxicities. Mar. Drugs 2020, 18, 551. [CrossRef] [PubMed]

19. Aminin, D.L.; Pislyagin, E.A.; Menchinskaya, E.S.; Silchenko, A.S.; Avilov, S.A.; Kalinin, V.I. Immunomodulatory and anticancer activity of sea cucumber triterpene glycosides. In Studies in Natural Products Chemistry; Rahman, A.U., Ed.; Elsevier Science, B.V.: Amsterdam, The Netherlands, 2014; Volume 41, pp. 75-94.

20. Kim, C.G.; Kwak, J.-Y. Anti-cancer effects of triterpene glycosides, frondoside A and cucumarioside $\mathrm{A}_{2}-2$ isolated from sea cucumbers. In Handbook of Anticancer Drugs from Marine Origin; Kim, S.K., Ed.; Springer International Publishing: Cham, Switzerland, 2015; pp. 673-682.

21. Careaga, V.P.; Maier, M.S. Cytotoxic triterpene glycosides from sea cucumbers. In Handbook of Anticancer Drugs from Marine Origin; Kim, S.K., Ed.; Springer International Publishing: Cham, Switzerland, 2015; pp. 515-528.

22. Kalinin, V.I.; Silchenko, A.S.; Avilov, S.A.; Stonik, V.A. Non-holostane aglycones of sea cucumber triterpene glycosides. Structure, biosynthesis, evolution. Steroids 2019, 147, 42-51. [CrossRef] [PubMed]

23. Kalinin, V.I.; Silchenko, A.S.; Avilov, S.A.; Stonik, V.A. Progress in the studies of triterpene glycosides from sea cucumbers (Holothuroidea, Echinodermata) Between 2017 and 2021. Nat. Prod. Commun. 2021, 16. [CrossRef] 